\title{
The Lifecycle of Silver in the United States in 2009
}

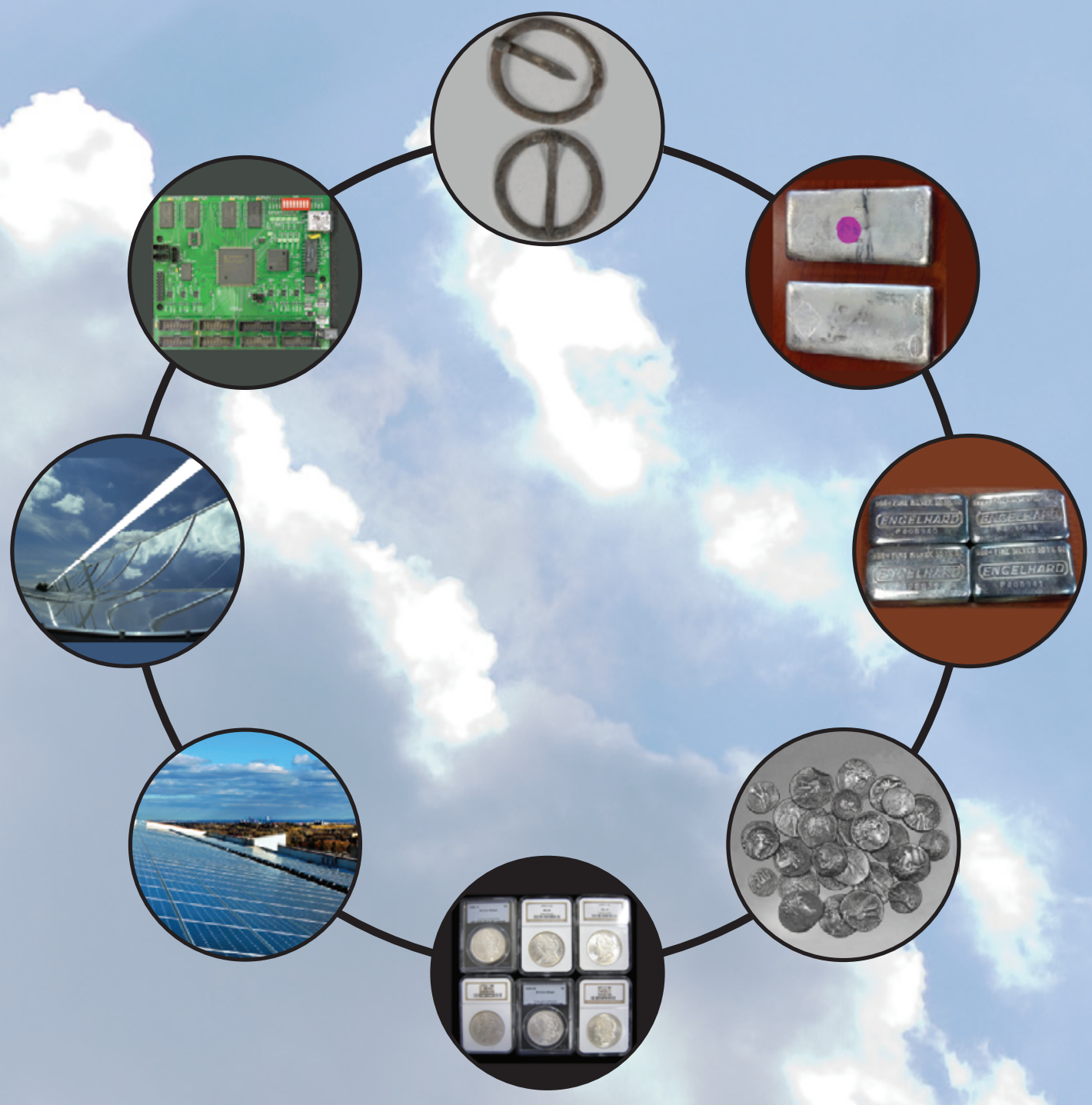

Scientific Investigations Report 2013-5178

U.S. Department of the Interior

U.S. Geological Survey 
Cover (clockwise from top). Silver alloy, circular-shaped annular brooches with hinged crossbars from Grand Portage National Monument (GRPO 14436); photograph from the National Park Service (http://www.nps.gov/media/photo/gallery. htm?tagID=13334). Silver bars; photograph from the U.S. Department of the Treasury (http://www.treasury.gov/auctions/ treasury/gp/dayton_coins.html). Silver bricks; photograph from the U.S. Department of the Treasury (http://www.treasury. gov/auctions/treasury/gp/dayton_coins.html). Silver coins from between 135 and 9 B.C.E. minted in Tyre; photograph from the Library of Congress (http://www.loc.gov/exhibits/scrolls/art2.html). Morgan silver dollar coins minted between 1881 and 1921; photograph from the U.S. Department of the Treasury (http://www.treasury.gov/auctions/treasury/gp/dayton_coins. shtml). Photovoltaic panels at the Research Support Facility at the National Renewable Energy Laboratory; photograph by Dennis Schroeder, National Renewable Energy Laboratory (http://www.nrel.gov/news/features/feature_detail.cfm/feature $i d=1760$ ? print). A concentrating solar power parabolic trough at Lawrence Livermore National Laboratory, at Livermore, California; photograph by Warren Gretz, National Renewable Energy Laboratory (https://www.eeremultimedia.energy.gov/ solar/photographs/line_focus_solar_collector). A motherboard connected to eight microboards in a microphone array; photograph from the National Institute of Standards and Technology (http://www.nist.gov/smartspace/mk3_presentation.html). 


\section{The Lifecycle of Silver in the United States in 2009}

By Thomas G. Goonan

Scientific Investigations Report 2013-5178 


\title{
U.S. Department of the Interior SALLY JEWELL, Secretary
}

\section{U.S. Geological Survey Suzette M. Kimball, Acting Director}

\author{
U.S. Geological Survey, Reston, Virginia: 2014
}

For more information on the USGS - the Federal source for science about the Earth, its natural and living resources, natural hazards, and the environment, visit http://www.usgs.gov or call 1-888-ASK-USGS.

For an overview of USGS information products, including maps, imagery, and publications, visit http://www.usgs.gov/pubprod

To order this and other USGS information products, visit http://store.usgs.gov

Any use of trade, firm, or product names is for descriptive purposes only and does not imply endorsement by the U.S. Government.

Although this information product, for the most part, is in the public domain, it also may contain copyrighted materials as noted in the text. Permission to reproduce copyrighted items must be secured from the copyright owner.

Suggested citation:

Goonan, T.G., 2014, The lifecycle of silver in the United States in 2009: U.S. Geological Survey Scientific Investigations Report 2013-5178, 17 p., http://dx.doi.org/10.3133/sir20135178.

ISSN 2328-0328 (online) 


\section{Contents}

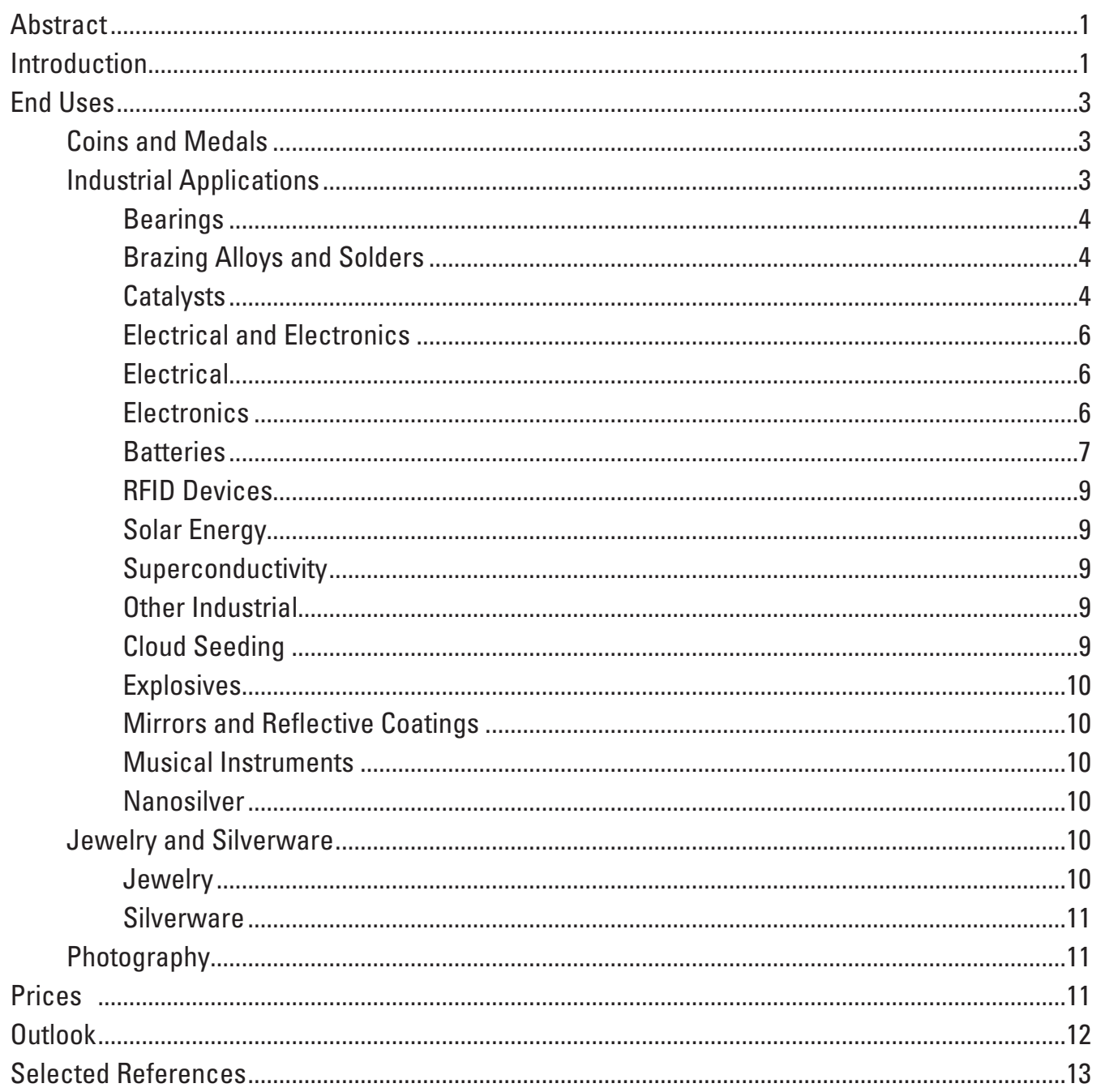

\section{Figures}

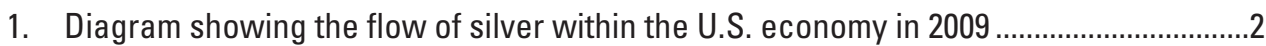

2. Graph showing the dollar and gold value of the silver in a pre-1964 U.S. dime

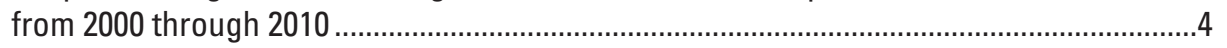

3. Graph showing the changes in U.S. silver fabrication from 2001 through $2010 \ldots \ldots \ldots \ldots \ldots . . . .5$

4. Graph showing the silver price and the silver-to-gold ratio from 1977 through 2011

\section{Tables}

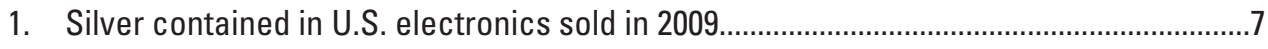

2. Silver contained in U.S. electronics scrap generated in 2009 ......................................... 


\section{Conversion Factors}

\begin{tabular}{lcl}
\hline \multicolumn{1}{c}{ Multiply } & By & \multicolumn{1}{c}{ To obtain } \\
\hline kilogram $(\mathrm{kg})$ & 2.205 & pound avoirdupois $(\mathrm{lb})$ \\
kilogram $(\mathrm{kg})$ & 32.1507 & troy ounce \\
ton, metric $(\mathrm{t}, 1,000 \mathrm{~kg})$ & 1.102 & short ton $(2,000$ pounds $)$ \\
part per million $(\mathrm{ppm})$ & 0.0001 & percent \\
\hline
\end{tabular}

\section{Datum and Supplemental Information}

Temperature in degrees Celsius $\left({ }^{\circ} \mathrm{C}\right)$ may be converted to degrees Fahrenheit $\left({ }^{\circ} \mathrm{F}\right)$ as follows:

$$
{ }^{\circ} \mathrm{F}=\left(1.8 \times{ }^{\circ} \mathrm{C}\right)+32 .
$$

\section{Abbreviations}

$\begin{array}{ll}\text { CdO } & \text { silver-cadmium oxide } \\ \text { CRT } & \text { cathode ray tube } \\ \text { EPA } & \text { U.S. Environmental Protection Agency } \\ \text { FDA } & \text { U.S. Food and Drug Administration } \\ \text { PV } & \text { photovoltaic } \\ \text { RFID } & \text { radio frequency identification } \\ \text { USGS } & \text { U.S. Geological Survey }\end{array}$




\title{
The Lifecycle of Silver in the United States in 2009
}

\author{
By Thomas G. Goonan
}

\section{Abstract}

Because silver is highly sought after for its properties, which make it eminently suitable for new technology applications, a clear understanding of the flow of materials in the economy, the historical context, and trends for the future can help project the future of silver in the economy of the United States. Silver has many properties that are desired in today's economy. It has superior electrical and heat conductivity, chemical stability, high-temperature strength, malleability, and other characteristics that make it important in high-tech electronic and other industrial applications. Because it is relatively scarce as a natural resource and is easily coined, silver historically has been an important monetary metal. As knowledge of silver chemistry has increased, many industrial end uses have been developed.

This study reviews the flows of silver into various end uses and examines the nature of the end use with respect to the silver properties desired and the ability of the end use to produce recyclable end-of-life materials. For the most part, silver can be profitably recycled, but the recycling activity is helped by tipping fees (fees imposed on scrap generators by scrap collectors for taking the material) for materials that might otherwise be regulated as hazardous wastes. New high-technology applications use silver in nanolevel amounts, leading to a potential for dissipative loss and reduced recycling capability.

\section{Introduction}

Silver can be found in the Earth's crust at 0.07 parts per million. About 30 percent of primary production (from ore rather than from scrap) of silver is mined from sulfide ores, for example, acanthite, prousite, pyrargyrite, and brittle (native) silver. Because silver occurs natively as the less dominant mineral in the ores that contain it, it is often obtained as a byproduct of refining these other metals, mainly lead and zinc (together accounting for 36 percent of silver obtained as a byproduct from the ore), copper (22 percent), and gold (11 percent) (The Silver Institute, 2011; Environmental Chemistry, 2012). Mine production worldwide in 2010 was 23,100 metric tons $(\mathrm{t})$; in order of magnitude, the major producers were Mexico, Peru, China, Australia, the United States, Chile, Bolivia, Poland, Russia, Canada, Kazakhstan, Argentina, and Turkey (Brooks, 2012). The first product of recovery from concentrate is called doré (an alloy of silver and gold), which is further processed into bullion (99.9 percent pure silver). Silver is also recovered from scrap (secondary production). Silver is fabricated into alloys, chemicals, and metal forms, which in turn are manufactured into products for various end uses.

Silver has many desirable physical properties that are economically important. Silver has high electrical and heat conductivity (exceeding that of all other metals), which is highly desirable for electronics and solar energy applications. Silver is also very malleable and ductile, properties in which it exceeds all other metals except gold (South Australia Department of Manufacturing, Innovation, Trade, Resources, and Energy, 2012). Silver halide salts are light sensitive, making them suitable for photography. The metal's light-reflective properties are essential for coating plane and spherical glass in the making of mirrors. Silver-copper alloys are used for coinage, flatware, jewelry, and along with other metals, solder. For millennia, silver and gold have been used as money. New technologies for purifying water, for sterilizing environments, and for medically treating wounds are growth areas for silver produced as nanosilver.

This report focuses on the end uses of silver, the flows of silver into these end uses, the scrap that these end uses generate, and where and how in the flow the scrap is collected and repurposed. The overall market for silver is the context within which these activities occur. The focus of the report and most of the data are for 2009; however, where available, later data have been included to provide a more current view of the lifecycle of silver in the United States.

Copper, gold, lead, silver, and zinc mines in the United States produced approximately 1,250 t of silver in concentrates in 2009. The stock and hedge book change (290 t) is calculated to be the difference between the reported production from concentrate $(1,250 \mathrm{t})$ minus the flows to exports of ore and concentrate (122 t) and the flow to U.S. smelting and refining $(838 \mathrm{t})$. The amount of silver flow from smelting and refining from concentrate is calculated from silver reported to be refinery production attributable to concentrate (796 t) using an assumed 95 percent recovery in processing. This 
calculation is based on the assumption that there is no net loss in processing scrap and that the category reported as ore and concentrate is mainly in the form of concentrate.

The recovery in concentrate of silver from polymetallic ores of copper, gold, lead, and zinc varies by ore type and deposit characteristics and ranges between 70 and 95 percent. For example, Hecla Mining Company (2013) reported mill recovery of 73 percent for silver at its Greens Creek lead and zinc mine.

In 2009 , the silver refinery production $(2,140 \mathrm{t})$ included silver from domestic and imported concentrates (796 t net of $838 \mathrm{t}$ input from mined sources) and scrap (1,340 t). Other silver sources for U.S. supply included refined stocks $(3 \mathrm{t})$, imports of refined silver $(3,450 \mathrm{t})$, and discharge from the stocks of futures exchanges (160 t). Of the total U.S. supply of refined silver $(5,750 \mathrm{t}), 5$ percent $(297 \mathrm{t})$ of silver was exported, and the remainder was flow into fabrication $(5,460 \mathrm{t})$. Another flow into fabrication was imports of semifabricated silver $(412 \mathrm{t})$ contained in gross imports of silver $(859 \mathrm{t})$. The total flow of silver into fabrication in 2009 was 5,870 t (fig. 1).

Fabricated silver products, chemicals, metal alloys and powders, and wrought forms are transformed by manufacturing activities into materials suitable for the major end uses, such as coins and medals, industrial applications (electrical, electronic, brazing alloys, and other), photography, and jewelry and silverware. In 2009, $698 \mathrm{t}$ of silver was exported as semifabricated product (chemical, forms, and powder, gross weight equal to $1,440 \mathrm{t}$ ).

In $2009,5,170 \mathrm{t}$ of silver contained in fabricated products was added to the product reservoir. The 5,170 t of contained silver in fabricated products was distributed among the major enduse categories as follows: industrial applications, 3,010 t; coins and medals, 1,070 t; photography, $728 \mathrm{t}$; and jewelry and silverware, 362 t. Home scrap generated in manufacturing activities is recovered and returned to the manufacturing processes.

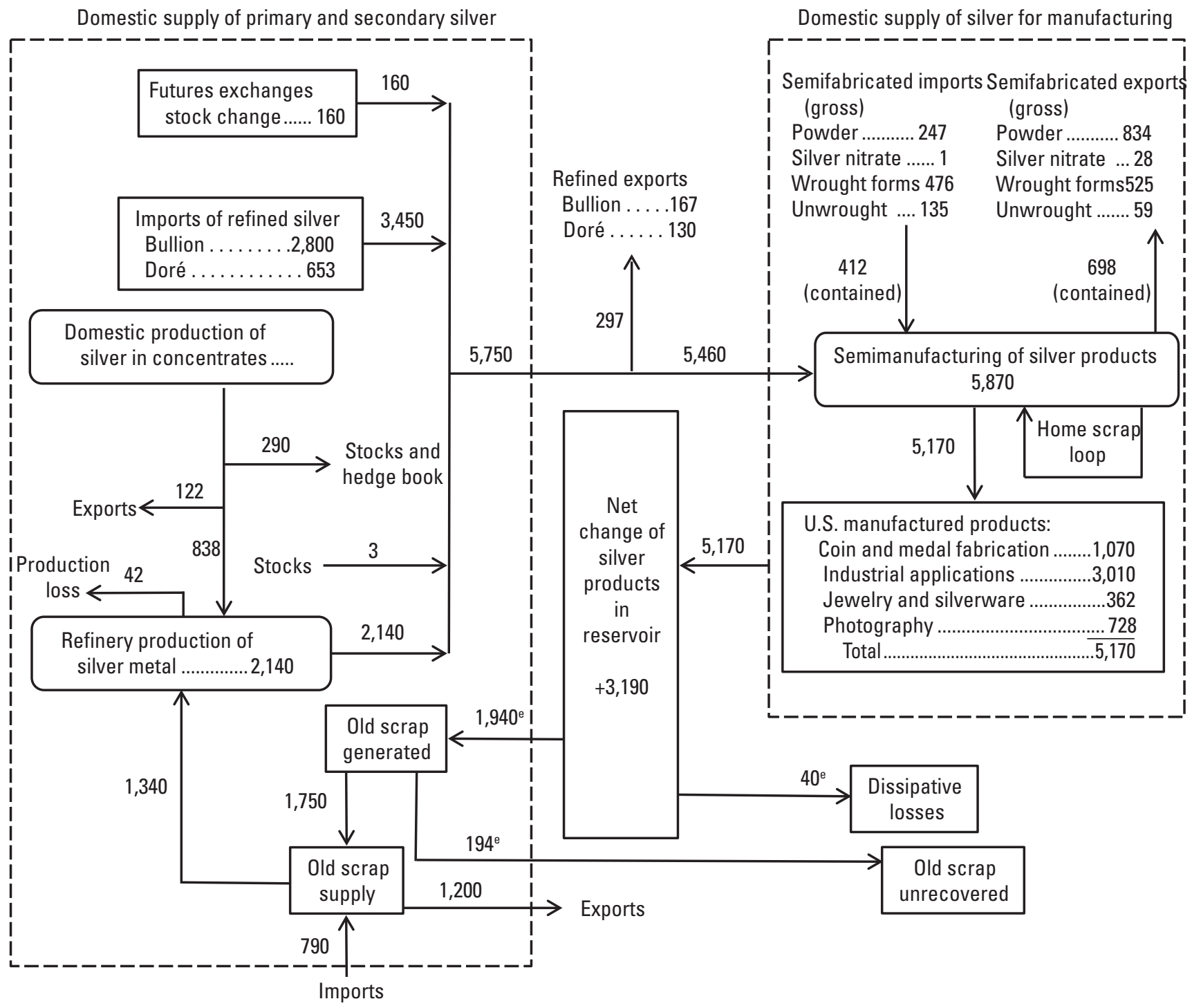

Figure 1. Flow of silver within the U.S. economy in 2009. Values are in metric tons. Data may not add to totals shown because of independent rounding. e, estimated from minimal data; does not include captive recycling or untaken recycling opportunities. 
It is estimated that the product reservoir lost about $40 \mathrm{t}$ of silver in 2009 through dissipative uses, such as cloud-seeding, explosives, nanosilver, and radio frequency identification (RFID) applications. Plated silver products can also generate dissipative losses over time; for example, silver-plated bearings will lose silver to wear, and silver-plated flatware will lose silver to oxidation and silver polishes. Furthermore, the product reservoir generated about 1,940 t of silver as old scrap, exclusive of captive (under contract) silver, such as scrap returned to producers of catalysts. About 90 percent of old scrap generated was recovered, and 10 percent was estimated to go unrecovered.

In 2009, the old scrap supply was augmented by inputs from imports (estimated to be $790 \mathrm{t}$ of contained silver) and the recovered portion (estimated to be 1,750 $\mathrm{t}$ of contained silver) of old scrap generated (estimated to be 1,940 t of contained silver). The supply was diminished by exports (estimated to be 1,200 $\mathrm{t}$ of contained silver) and uptake to refining (1,340 t of contained silver).

The sum of all silver ever recovered from historic mining activities worldwide is estimated to be about 1.5 million metric tons (Mt; 47 billion troy ounces) (Butterman and Hilliard, 2004; Porter and others, 2011). Zurbuchen (2006) estimated the aboveground silver inventory (silver in use) to be $650,000 \mathrm{t}$ ( 21 billion troy ounces) in 2006, or about 46 times the silver that global industrial applications alone required and 24 times the total required for all fabrication needs in 2006. If these estimates are reasonably correct, then about 55 percent of all of the silver ever produced in the world has been lost or dissipated.

\section{End Uses}

There are numerous end uses for silver. The Silver Institute annually reports worldwide, country-by-country use of fabricated silver as distributed into four major end-use categories - coins and medals, industrial applications, jewelry and silverware, and photography. The industrial category is further divided into four subsectors - bearings, brazing alloys and solders, catalysts, electrical use and electronics; and other industrial applications (The Silver Institute, 2011).

The industrial and photographic end-use categories seek silver for its intrinsic physical properties - its superior electrical and heat conductivity, its malleability, photosensitivity, reflectivity, and strength, and its toxicity to bacteria and viruses for the nanosilver uses. Although photography is still a popular end use for silver, consumption of silver has decreased in this use with the growth of digital photography; instead, medical and industrial $\mathrm{x}$ rays predominate in the photographic end use. Important everyday industrial uses for silver include batteries (rechargeable and disposable) for cameras, electronic devices, tools, and watches; catalysts for the manufacture of ethylene oxide and formaldehyde, which are fundamental precursors for plastics manufacturing; chemicals (mainly salts), which are precursors for manufacturing other chemicals and for plating silver onto other metal surfaces (for example, silver-coated steel bearings in high-temperature applications, such as turbines); electrical contacts for switches and fuses (an automobile may have as many as 40 silver-tipped switches); electrical pastes for use in the control boards of computers and flat-panel displays and for photovoltaic arrays that produce electricity from solar energy; electrical relays and circuit breakers; and reflective uses, for eyewear, mirrors, and thermal windows. Nanosilver has germicidal characteristics that have generated a new category of use for silver in recent years as additions to textiles, wound dressings, and public water-supply treatments (Ruff, 2008).

Total silver fabrication in the United States showed some fluctuation from 2001 through 2010. There was a marked decrease in use of silver for photography (discussed in the Photography section), but growth in use of silver for industrial applications and for coins and medals mostly offset the decreases in other sectors. On average, industrial applications from 2001 through 2010 consumed about $126 \mathrm{t}$ of additional silver than each previous year.

\section{Coins and Medals}

The flow of silver into fabrication of coins and medals in 2009 was 2,460 $t$ worldwide and 1,070 $t$ for the United States (The Silver Institute, 2011, p. 82). The compound annual growth rate for this end-use classification from 2001 through 2010 was 16.2 percent worldwide and 16.4 percent for the United States (fig. 2).

The gold value of the silver ${ }^{1}$ contained in a pre-1964 U.S. dime, which contained 0.0715 troy ounce of silver, was

\footnotetext{
${ }^{1}$ A price is a trading ratio of dollars to weight of a commodity. The gold value of silver is the price of silver at a particular time divided by the price of gold at that particular time; this calculated ratio reflects approximately the supply and demand for gold and silver at that time.
}

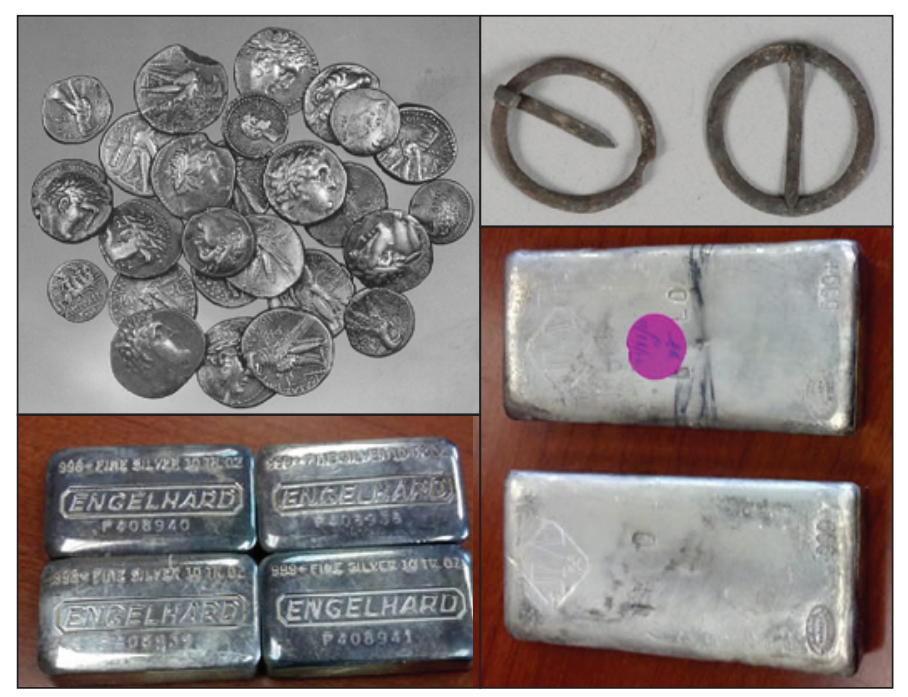


Figure 2. Dollar and gold value of the silver in a pre-1964 U.S. dime from 2000 through 2010. The pre-1964 U.S. dime containing 0.0715 troy ounces of silver.

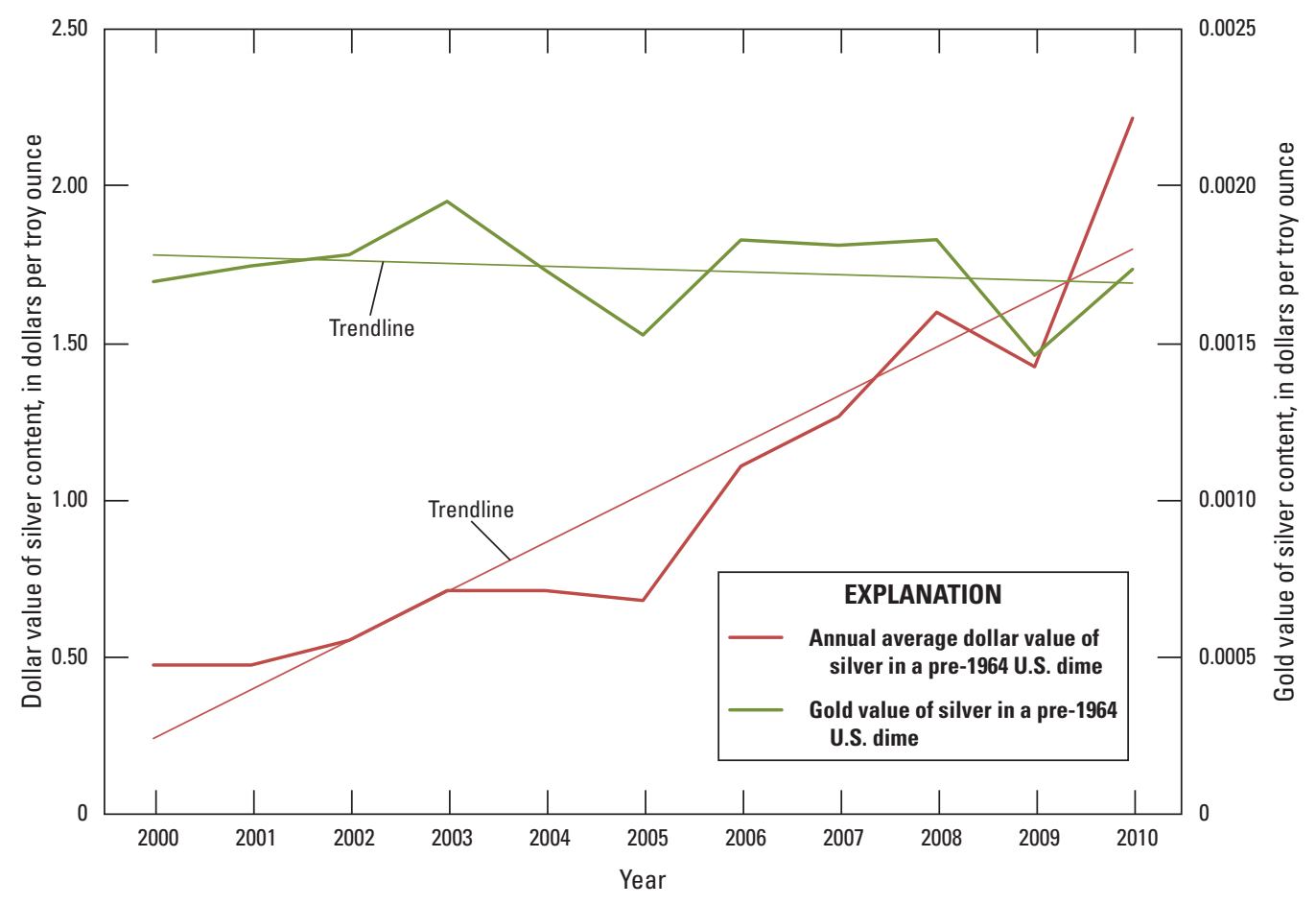

virtually constant from 2000 through 2010, whereas the dollar value for the silver in the same dime increased by about 360 percent. The rate of increase for the dollar value of silver contained in the pre-1964 U.S. dime is comparable to the 333 percent increase in the flow of silver into the coin end use. The increase in the flow of silver into the coins and medals end use is significant for the purposes of this report.

In 2011, sales of American Silver Eagle ${ }^{2}$ coins were estimated to account for $1,240 \mathrm{t}$ of silver, exceeding for the first time the production of silver from domestic mines, which was estimated to have decreased to $1,120 \mathrm{t}$ (Kramer, 2013). This trend, which is also currently (2013) taking place in Canada (St. Angelo, 2012), indicates the strong demand for silver because of the monetary properties of the metal.

\section{Industrial Applications}

The flow of silver into industrial applications in 2009 was 12,600 $t$ worldwide and 3,010 $t$ for the United States (The Silver Institute, 2011, p. 86). From 2001 through 2010, the compound annual growth rate for this end use was 3.8 percent worldwide and 4.3 percent for the United States. During the same period, the use of silver going into industrial applications grew from less than 2,400 $\mathrm{t}$ (46.4 percent) to about 3,600 t (60.6 percent) of total fabrication of silver in the United States (fig. 3). Predominant uses of silver in industrial applications include bearings, brazing alloys and solders, catalysts, electrical and electronic applications, and other applications.

\footnotetext{
${ }^{2}$ American Silver Eagles are 1-ounce silver coins that contain 0.999 fine silver and are domestically produced for investors and collectors, not for currency.
}

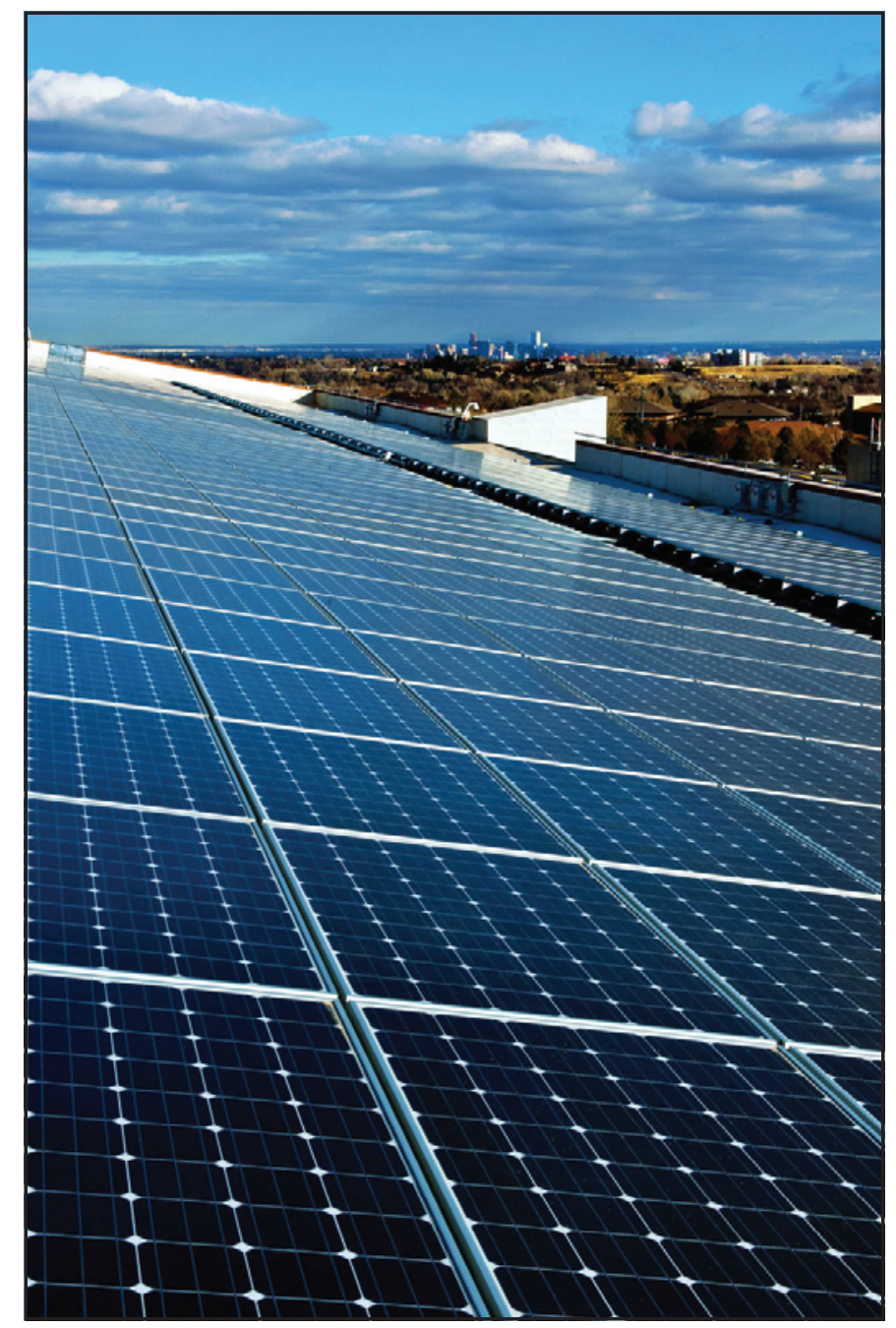


Figure 3. Changes in U.S. silver fabrication from 2001 through 2010.

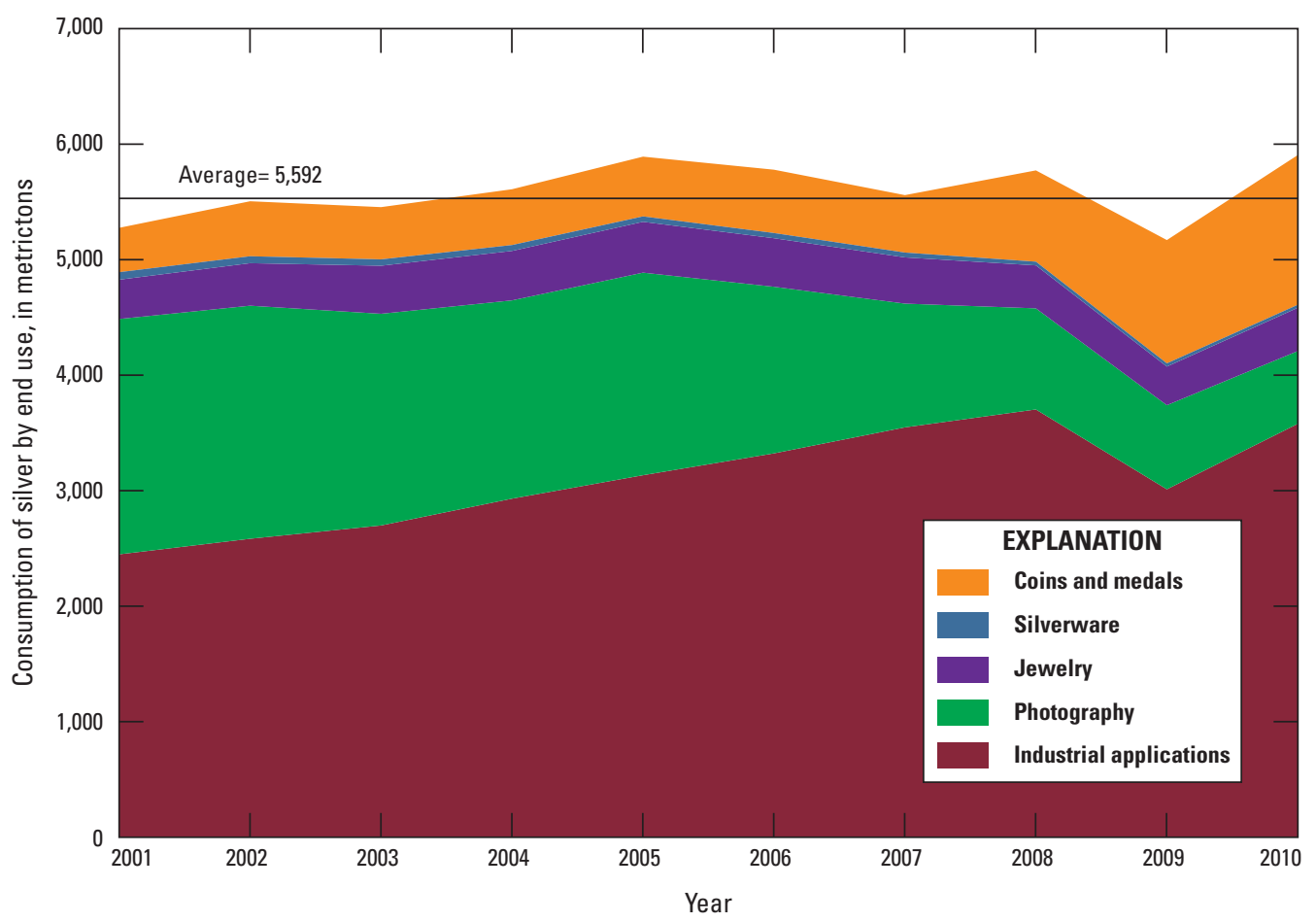

\section{Bearings}

Silver-coated bearings are used extensively throughout industry, where high load-bearing specifications and requirements for high-temperature strength and thermal conductivity exist, predominantly in heavy machinery, aircraft, and hightechnology applications. Silver exhibits superior resistance to corrosion and fatigue and has a low friction characteristic that enables it to lubricate steel parts by providing a film of silver coating between moving parts (Silver Insights, 2012a).

Silver is applied to the surface of bearings by electrolysis in quantities measured in nanograms per bearing (Loterijman, 2008, p. 14). In 2009, worldwide application of silver for bearings was estimated to be $64 \mathrm{t}$ (Firman and others, 2011, p. 25). Because silver is plated onto bearings, it can be and is recovered from bearings scrap. The actual amount of silver recovered from recycled bearings is unknown.

\section{Brazing Alloys and Solders}

Brazing is the joining of two pieces of different metal composition (by means of a metal alloy that adheres to both at high temperatures); soldering is similar, but it is useful only at lower temperatures. Primary users of silver brazing alloys are the plumbing and automobile industries and manufacturers of heating, ventilation, and air conditioning equipment (Nadal and others, 2011, p. 8). Global silver consumption for brazing and soldering was 1,680 $\mathrm{t}$ in 2009, whereas in the United States it was about $162 \mathrm{t}$.

Some of the more than 100 types of silver brazing alloys include copper, silver, and phosphorus alloys (1 to 15 weight percent silver); silver and copper alloys (50 to 93 weight percent silver); silver, copper, and zinc alloys (5 to 75 weight percent silver); silver and palladium alloys (45 to 95 weight percent silver); Wieland dental alloys (12 to 34 weight percent silver); and ceramic brazing alloys (57 to 98 weight percent silver). These alloys nominally average about 43 percent of contained silver. Worldwide application of silver for brazing alloys in 2009 was estimated to be 1,270 $\mathrm{t}$ (Firman and others, 2011, p. 25) or 1,892 t (The Silver Institute, 2011). Loterijman (2008, p. 13) estimated that the collection rate for brazing alloy scrap is about 40 percent.

\section{Catalysts}

Silver catalysts are prominent in the production of two primary building-block chemicals, ethylene oxide and formaldehyde. Worldwide, more than 4,670 t of silver is used as catalyst for the production of both chemicals -90 percent for producing ethylene oxide from ethylene, and 10 percent for producing formaldehyde from methanol (The Silver Institute, 2012a).

Ethylene oxide is a precursor chemical for the polyester used in textile manufacturing. Polyester is also an ingredient in molded plastics used for stove handles, computer keys, electrical control knobs, and housings for electrical connectors. About 25 percent of ethylene oxide is used to manufacture ethylene glycol, which is used as antifreeze for automobiles (The Silver Institute, 2012a). Worldwide, about $30 \mathrm{Mt}$ of ethylene oxide is produced per year, requiring about $4,200 \mathrm{t}$ of the silver contained in catalysts (Crudge and others, 2011; The Silver Institute, 2012a). As ethylene from shale gas becomes a more important source of petrochemicals, demand for silver to produce downstream chemical products is expected to increase 
significantly (Jeffrey R. Ellis, senior technology consultant, The Silver Institute, written commun., February 11, 2013). The economic service life of silver catalysts in ethylene oxide reactors is about 2.5 to 3 years, at which time the catalyst is removed and replaced, and the spent catalyst is recovered and sent on within the flow for recycling (Crudge and others, 2011).

Formaldehyde is primarily used in the manufacture of resins, which are substances that become sticky liquids at moderate temperatures and can be easily molded into useful shapes that harden at ambient temperatures. Worldwide consumption of formaldehyde was about $20 \mathrm{Mt}$ in 2005, and the United States consumed 24 percent (5 Mt) of world consumption (Nexant Chem Systems, 2006).

The two processes that are used to produce formaldehyde use methanol as feedstock. One uses a molybdenum-based catalyst for partial oxidation, whereas the other uses a silverbased catalyst for partial oxidation and dehydrogenization. The silver-based catalysts were the predominant use in 2005, although some plants built after 2000 had experimented with molybdenum-based catalysts. However, an assessment by Etris (2007) found silver to be favorably competitive with molybdenum-based catalysts. The lifespan of silver catalysts is typically 1 year, but the catalyst can be electrolytically regenerated (Nexant Chem Systems, 2006).

Recovery of catalysts, and therefore of silver, by recycling or by regeneration for producing ethylene oxide and formaldehyde is usually undertaken by the catalyst suppliers. The reasons that chemical industries do not undertake recovery are that environmental regulations would treat spent catalysts as hazardous wastes if catalysts were disposed of rather than recycled and that anti-money-laundering regulations are partly directed toward handlers of large quantities of precious metals, recovery of which conserves resources (Bullock, 2005; Department of the Treasury, 2005). By creating and handling metal inventory accounts for the operators, purchasing the makeup material requirements, and dealing with the paperwork required by regulators, catalyst suppliers perform a valuable service to an operating chemical company. Finally, they supply new catalyst on an as-needed basis (Krauter, 2012, p. 10-11).

The metal losses that occur in recycling are due to process parameters, such as the contracted credit for the metal, to inaccuracy in sampling and waste characterization, and to the need for frequent handling of the waste at different points during collection and metallurgical processing. The recycler must also cover the costs of administration, insurance, logistics, penalties and surcharges, transport, and treatment and refining charges. Additionally, there are financing costs (for example, contracted return time, delays, lease rates and conditions, pretreatment, shipment timing, and time for disposing of the recycled metals). These considerations relate to risk and return. When operators and suppliers work on long-term contracts, the risk is minimized because the materials-flow history is known to both and trust between the parties has been established (Hagelüken and Verheist, 2004).

\section{Electrical and Electronics}

Silver has the lowest electrical resistivity (1.586 microhm-centimeters at 20 degrees Celsius $\left({ }^{\circ} \mathrm{C}\right)$ ) of all elements; because conductivity is the reciprocal of resistivity, silver has the highest electrical conductivity of all elements (Handbook of Chemistry and Physics, 1988, p. F 88). The electrical and electronics end use accounted for 5,770 $t$ of silver used in 2009. This was 24 percent of all silver fabricated $(24,200 \mathrm{t})$ worldwide. The United States, with a flow of 1,630 t of silver to electrical and electronic use (32 percent of U.S. silver use), accounted for 7 percent of the total fabrication use worldwide (The Silver Institute, 2011, p. 84, 88). Although demand for electrical and electronics end uses continues to grow, growth in the use of silver within this category can be "mitigated by thrifting," that is, by developing and using cheaper materials, especially for circuitry (Jeffrey R. Ellis, senior technology consultant, The Silver Institute, written commun., February 11, 2013).

\section{Electrical}

Most appliances, devices, and machines that operate using electric power have points of contact, wiring or circuit boards, and electrical components made of silver alloy. These uses make up about 5 percent of total U.S. silver use (Silver Insights, 2012b). About $675 \mathrm{t}$ of silver was used in the United States for electrical purposes in 2009 (Nadal and others, 2011, p. 6).

Automobiles may contain as many as 40 miniature motors that have silver-containing electrical contacts; a typical vehicle may contain as much as $16 \mathrm{~g}$ (about 0.5 troy ounces) of silver (Minco Silver Corporation, 2012, p. 4). Different silver alloys are used for making contacts, but the most common is coin silver, which contains about 90 percent silver. Circuit breakers and switching devices are made from silver and nickel alloy, which can contain 85 to 95 weight percent

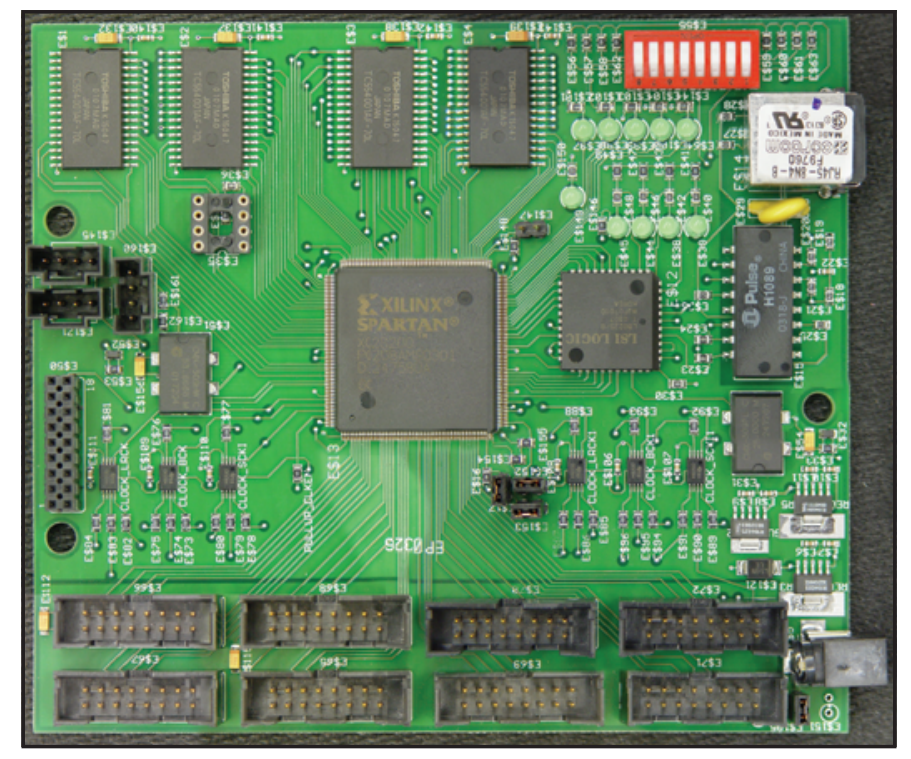


silver (CJ Environmental, Inc., 2012). One electrical-contact manufacturer of buttons, facings, screws, shapes, strip, rivets, and wire uses the following alloys: coin silver (90 percent silver and 10 percent copper), fine silver (99.9 percent silver), composites of cadmium oxide $(\mathrm{CdO})$ and silver (the content of $\mathrm{CdO}$ varies and can be as much as 13.3 weight percent), silver and graphite alloy (the content of graphite varies and can be 1 weight percent), and silver and nickel alloy (the content of nickel varies, and can be as much as 15 weight percent) (CMW, Inc., 2012).

The collection of scrap from this end use is informal. In the past, sellers (collectors) have been electricians or workers in construction demolition, but now, amateurs who understand the income possibilities for recycling silver contacts are becoming collectors of scrap in this end use (Cash for Gold Insider, 2012, written blog commun., accessed July 30, 2012, at http://www.cashforgoldinsider.com/scrap-silver-electricalcontacts/). The recovery of silver from scrap electrical contacts is undertaken in smelting facilities that have gas collection and cleaning systems affixed. Electrical contacts have other associated metals, such as cadmium (highly toxic), that are driven off as fume under high temperature. In one case, a batch (3.4 kilograms (kg) gross weight) of electrical contacts was melted for assay, yielding a bar $(2.5 \mathrm{~kg}$ net weight metal $)$ of which 94 percent, or about 74 troy ounces, was silver. This example shows that scrap from this category can be productive of silver, but that there are substantial uncategorized losses, some of which can probably be found in unseparated tin and silver alloy that is used to make the contacts (Canada Gold Buyers, 2012). Silver-containing electrical-contact scrap is traded under contracts between buyers and sellers, the contracts providing for an assay of the material that is mutually agreeable. The extent of such trade cannot be determined from available data.

\section{Electronics}

This category of end use includes computers and peripheral devices, hand-held devices, telephones, and televisions, all of which have printed circuit boards that organize electrical signals. Most of the silver contained in these items (ratios from 0.1 to 0.33 weight percent, with averages of about 0.156 percent of the weight of the circuit board) is found on the circuit board (Hagelüken, 2007, p. 7; Chehade and others, 2012, p. 227; Appropedia, undated, p. 3). About $955 \mathrm{t}$ of silver was used in the United States for manufacturing electronics devices in 2009 (Nadal and others, 2011, p. 6).

The U.S. Environmental Protection Agency (EPA) reported U.S. sales of electronic devices, including computers, telephones, and televisions, for 2009 (U.S. Environmental Protection Agency, 2011a). The data on sales of units of electronic devices were converted into the gross weight of these units in metric tons of contained silver per unit. Based on other estimates of weight percent ratios of contained silver in such devices (Goosey and Kellner, 2002; Recycling Today, 2003; Hagelüken, 2007; Chatterjee and Kumar, 2009; Kahhat and others, 2011; Sullivan, 2006; Minco Silver Corporation, 2012), about $484 \mathrm{t}$ of silver was estimated to be contained in computers, telephones, and televisions sold in the United States in 2009 (table 1). This estimate differs from the report on the use of silver in manufacturing such devices $(955 \mathrm{t})$ in 2009 from Nadal and others $(2011$, p. 6). Table 1 presents estimates of the content of silver in the sales of these devices in 2009. The estimate of U.S. sales is based on the EPA's report (2011a) of sales of electronics in 2009 in those categories and silver per unit or silver weight percent estimates from the sources listed in table 1 .

The EPA report also estimated scrap generated, collected, and disposed of in 2009 (U.S. Environmental Protection Agency, 2011a). To estimate the scrap generated from each category of electronics end use in 2009, the EPA estimates of useful life were used to impose a statistical distribution on the EPA time series of sales by category of end use. Using the same estimates of silver content that generated table 1, estimates were developed of the silver content of the scrap arising in each such category (table 2).

The United States generated 372 million units (gross weight $2.54 \mathrm{Mt}$, containing about $186 \mathrm{t}$ of silver) of electronic scrap from in-use stocks of computers, computer peripheral devices, telephones, and televisions in 2009. About 675,000 t (27 percent by weight) of this generated electronic scrap was collected, of which $223,000 \mathrm{t}$ (33 percent) was refurbished and resold, and the remaining 452,000 t (67 percent) was recycled (table 2). Of the $186 \mathrm{t}$ of silver contained in the electronic

Table 1. Silver contained in U.S. electronics sold in 2009.

[Data are from Goosey and Kellner (2002), Recycling Today (2003), Hagelüken (2007), Chatterjee and Kumar (2009), Kahhat and others (2011), U.S. Environmental Protection Agency (2011), Encyclopedia of Earth (2012), and Minco Silver Corporation (2012)]

\begin{tabular}{lcrc}
\hline \multicolumn{1}{c}{ End use } & $\begin{array}{c}\text { Units sold, } \\
\text { in millions }\end{array}$ & $\begin{array}{c}\text { Gross } \\
\text { weight, in } \\
\text { metric tons }\end{array}$ & $\begin{array}{c}\text { Silver content, } \\
\text { in metric tons }\end{array}$ \\
\hline Computers: & 26.3 & 263,000 & 26 \\
Desktop & 46.4 & 135,000 & 65 \\
Laptop & 29.5 & 233,000 & 9 \\
Printers & 33.1 & 43,500 & 17 \\
Keyboards & 27.2 & 303,000 & 272 \\
Flat panel & 163.6 & 977,000 & 389 \\
$\quad$ monitors & & $1,170,000$ & 32 \\
Total & 32.1 & 39,900 & 2 \\
Televisions: & 0.6 & $1,210,000$ & 34 \\
Flat panel display & 32.7 & 19,600 & 62 \\
Projection (type) & 216.1 & $2,210,000$ & 484 \\
Total & 411.4 & & \\
Mobile devices ${ }^{1}$ & & & \\
Total & & &
\end{tabular}


Table 2. Silver contained in U.S. electronics scrap generated in 2009.

[Data are from Goosey and Kellner (2002), Gale Group (2003), Hagelüken (2007), Chatterjee and Kumar (2009), Kahhat and others (2011), U.S. Environmental Protection Agency (2011), Encyclopedia of Earth (2012), and Minco Silver Corporation (2012)]

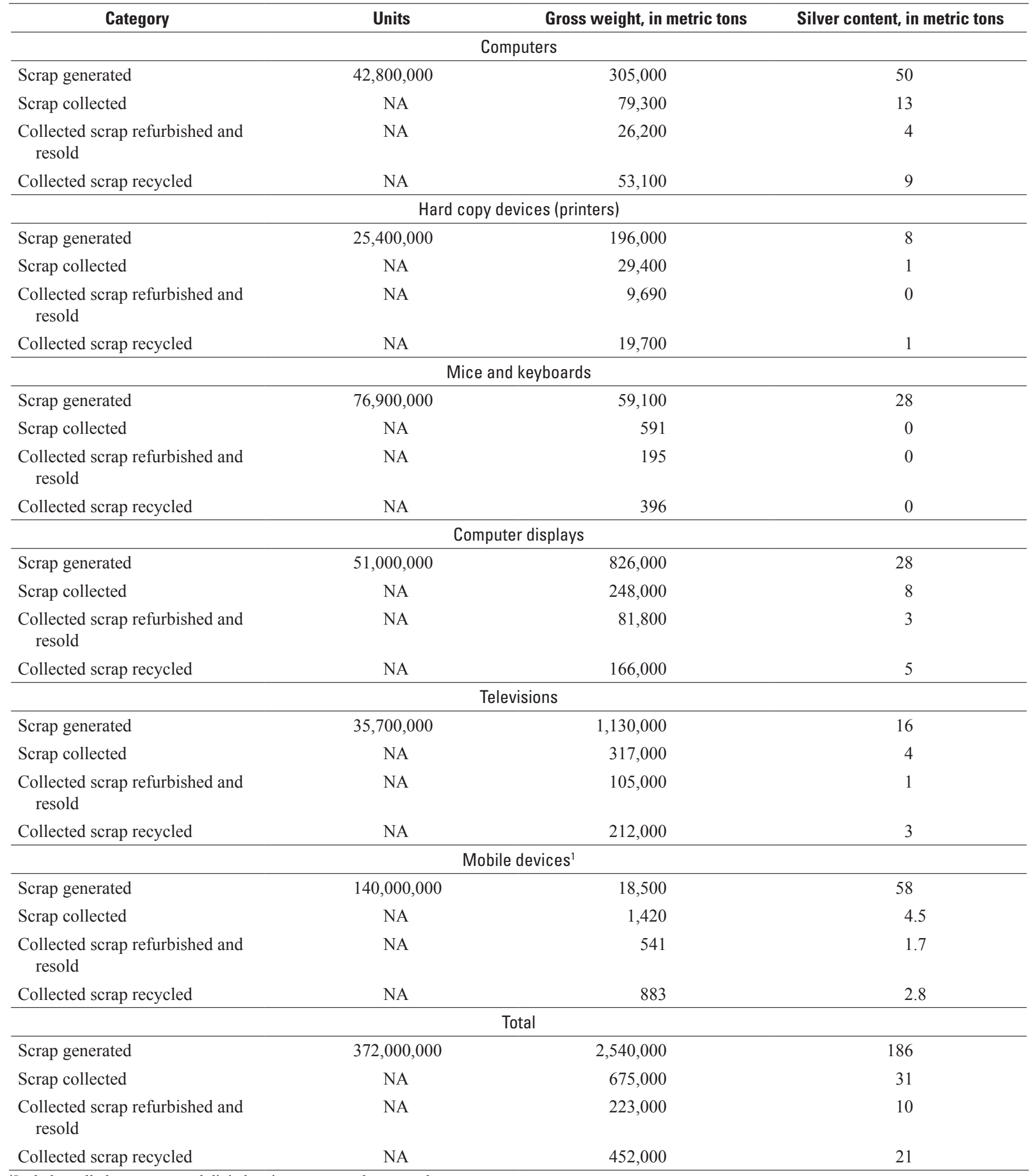

${ }^{1}$ Includes cell phones, personal digital assistants, smartphones, and pagers. 
scrap, $31 \mathrm{t}$ was collected, of which $10 \mathrm{t}$ was contained in refurbished materials, and $21 \mathrm{t}$ was sent to recyclers. Of the total 372 million generated units of electronic scrap, 50.2 million units (about 13 percent of generated units and 48 percent of generated scrap weight) are represented by the scrap from cathode ray tubes (CRTs). This scrap contained a statistically insignificant amount of silver (about 0.0157 grams per unit, embodied as a dopant in blue phosphor) (Donahue, 1957; Sheppard and Cavette, 2012, p. 3). As CRT scrap becomes exhausted, scrap from newer technologies will yield more silver per unit generated. Electronic scrap also includes other metals of interest, including copper, gold, indium, palladium, platinum, and certain rare earths (Buchert and others, 2012, p. 30).

\section{Batteries}

Silver oxide button-cell batteries function with a medium drain on power and are used in watches, toys, and calculators (RIS International, 2007, p. 19). Silver oxide batteries contain about 31 weight percent silver (Fisher and others, 2006, p. 56). Each button cell weighs on average 1.2 grams, ranging from 0.12 to 2.55 grams (RIS International, 2007, p. 35). It has been estimated that more than 1.5 billion silver oxide batteries are produced worldwide every year, which would require nearly $560 \mathrm{t}$ of silver each year (MexZotic, 2012). Because the service life of a silver oxide battery averages from 1 to 3 years (Microbattery, 2012), as much as $500 \mathrm{t}$ of silver contained in these batteries becomes available as scrap every year. Few data are available regarding the extent of silver oxide battery recycling.

Although there is a formal rechargeable battery recycling program in the United States, silver oxide batteries are not rechargeable and are not included in this program. Recycling of button-cell batteries is limited to local battery collection programs. Jewelers and large retailers collect the batteries when customers need to replace them, and the batteries are usually recycled through pyrometallurgical techniques at copper smelters. Recyclers, who handle diverse types of silver scrap, solicit for silver oxide battery scrap that has been separated from other types of battery scrap. They will typically offer a price for silver oxide battery scrap that is expressed in dollars per pound of batteries, which is about the same as the spot price for silver (determined in dollars per troy ounce). For example, if the spot price for silver is $\$ 20$ per troy ounce, the buyer of silver oxide batteries will offer $\$ 20$ per pound of batteries. When the difference in units is considered, the buyer of silver oxide battery scrap is paying about 20 percent of the spot price of silver for the silver contained in the battery (Arch Metal Refining, 2011).

Canadian $^{3}$ experience regarding the handling of silver oxide batteries is instructive. In 2010, 10.3 million units of silver oxide batteries were sold, which was 1.7 percent

\footnotetext{
${ }^{3}$ The Canadian experience is a suitable proxy for U.S. data that are, for whatever reason, unavailable because the silver oxide battery markets behave in very similar terms in the two countries.
}

of primary "nonrechargeable" Canadian battery sales (621 million units). Also in 2010, 10.6 million units of silver oxide batteries were discarded, which was 2.2 percent of all primary batteries discarded (478 million units). Furthermore, 0.2 million units of silver oxide batteries were recycled (recycling rate was 2 percent), the unrecycled silver oxide batteries were disposed of in landfills (RIS International, 2007, p. ii-v). This means that there is potential for increased silver recovery by means of increased recycling of silver from silver oxide batteries.

\section{RFID Devices}

RFID devices can transmit information from the packages that contain them; silver ink antennae, which are printed onto a paper substrate, serve as the transmitter. These devices replace manual labor for tracking and sorting and are a growing end use for silver, which is more reliable and less expensive than copper or aluminum substitutes. RFID devices contain about 10.9 milligrams (mg) of silver per unit (Loterijman, 2008, p. 15).

Worldwide use of silver for RFID devices in 2009 was estimated to be $48 \mathrm{t}$, with expected increased demand (multiple billions of units) as the technology overcomes problems of standardization (Firman and others, 2011, p. 25). In 2009, this was a dissipative use for silver, all of the silver being accounted for as lost in paper recycling or in other common waste disposal activities. RFID devices follow the recycling routes of the items to which they are attached, for example, chips attached to cardboard boxes for the purpose of tracking will be recycled with the cardboard. Maltby and others (2005, p. 16) estimated that 85 percent of the silver input through the cardboard recycling stream was lost to discharges to water and to landfills, and the remainder was dissipated within the cardboard recycling route.

\section{Solar Energy}

Photovoltaic (PV) panels that contain various components, mainly silica, collect sunlight and transform the solar energy into electrical energy. Different configurations of the panels yield more or less energy from a given solar flux, with corresponding differences in cost. So-called thick-film (crystalline silicon) PV panels represented about 90 percent of the industry in 2011 (Carlson, 2012).

About 64.3 t (2,000 troy ounces) of silver (as silver paste) per megawatt of electricity output capacity is applied to thick-film solar cells (Carlson, 2012). The United States added 464 megawatts of electricity capacity from thick-film PV generation in 2009, the equivalent of $26 \mathrm{t}$ of silver, and world capacity of electricity increased by 7,200 megawatts from thick-film PV generation, equivalent to 403 t of new silver use. Additional U.S. capacity of 897 megawatts of electricity as thick-film PV, equivalent to $50 \mathrm{t}$ of silver, was installed in 2010.

Solar energy can be converted to electrical or thermal energy by means of convex spherical glass mirrors, the rear surfaces of which are silverized, becoming reflectors that 


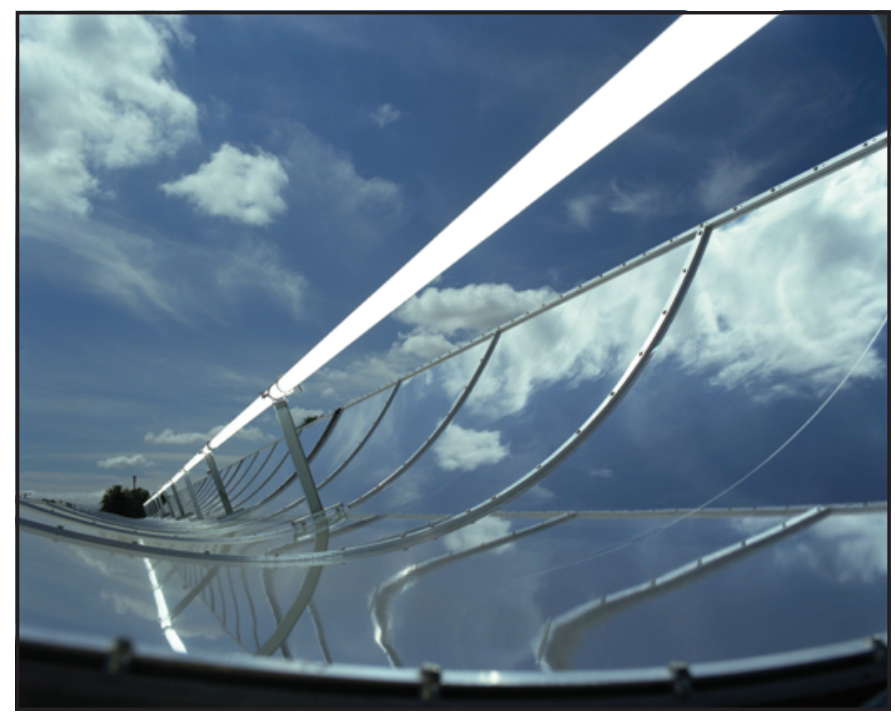

focus energy at a point (Krothapalli and Greska, 2011, p. 6). Such solar energy-generation facilities are called "concentrating" facilities; there are several focusing technologies and include trough, Fresnel, tower, dish, and other lenses.

In 2012, the United States added 508 megawatts of operational capacity concentrating technologies, 1,010 megawatts of capacity was under construction, and 3,870 megawatts of capacity was as announced projects, representing $4.4 \mathrm{t}$, $8.2 \mathrm{t}$, and $32 \mathrm{t}$, respectively, of silver at 1 gram of silver per square meter of collector area for the given mirror assembly (Cheryl Kennedy, senior scientist, National Renewable Energy Laboratory, written commun., October 19, 2012). An additional 725 megawatts of off-grid solar-powered capacity (representing about $6.4 \mathrm{t}$ of silver coating the rear surface of the highly polished glass) was directed to heating and cooling the interiors of buildings and to heating swimming pools in the United States in 2009 (Sherwood, 2011, p. 13-14).

Solar energy systems are expected to have lifetimes ranging from 20 to 40 years, so near-term generation of scrap from this end use will most likely be in the form of prompt scrap generated in the manufacture of solar panels. The recent (2012) collapse in prices of solar-energy-producing units and the development of thin-film technologies, for the time being, have greatly decreased the demand for high-performance materials, including silver (Jeffrey R. Ellis, senior technology consultant, The Silver Institute, written commun., February 11, 2013).

\section{Superconductivity}

Superconductivity is the property of materials that lets them transfer electric currents without resistance. Many materials exhibit this property at very low (cryogenic) temperatures, the transition to zero resistance occurring at a definable temperature called the "critical transition" temperature. The practical meaning of this phenomenon is that narrow-gage wires can be used to transport electrical currents over long distances with little energy loss (with improved efficiency).
Although silver is highly conductive at ambient temperatures, it is not a superconducting material because it does not exhibit the critical-temperature transition to zero resistance. However, there is much research into the effects that silver adds to a superconducting compound; it introduces low-temperature malleability to the compound without adding to the compound's resistance. As energy conservation and efficiency become more significant in the future, the field of superconductivity may become practical beyond the laboratory and beyond subsidized pilot-demonstration projects (Silver Insights, 2012e).

\section{Other Industrial}

Of five other nonelectrical uses for silver in the industrial sector, some have a long history, and others are based on new technologies. These nonelectrical uses for silver include cloud seeding, explosives, mirrors and reflective coatings, musical instruments, and nanosilver.

\section{Cloud Seeding}

For more than 50 years, silver iodide has been used in combination with the salts of other chemicals for the process known as rainmaking. Silver iodide is preferred because it creates ice nuclei in clouds at higher temperatures (about $-5^{\circ} \mathrm{C}$ ) than alternative chemicals (Griffith and Yorty, 2009, p. 18). Seeding generators burn solutions of acetone containing about 2 to 3 percent silver iodide by weight (Griffith and Yorty, 2009 , p. 22). With airborne seeding, consumption rates of typical silver iodide are about 2 gallons per hour per generator, which results in a release rate ranging from 120 to 180 grams of silver iodide ( 55 to 83 grams of silver) per hour (Griffith and Yorty, 2009, p. 27).

The U.S. Public Health Service estimated that $3 \mathrm{t}$ of silver was released in 1978 to the environment from cloudseeding operations (Eisler, 1996, p. 5). Virtually all the silver used for this purpose is dissipated to the environment, but not in amounts that exceed regulatory limits (Griffith and Yorty, 2009, p. 174). Little information is available on silver iodide use in cloud-seeding activities from year to year.

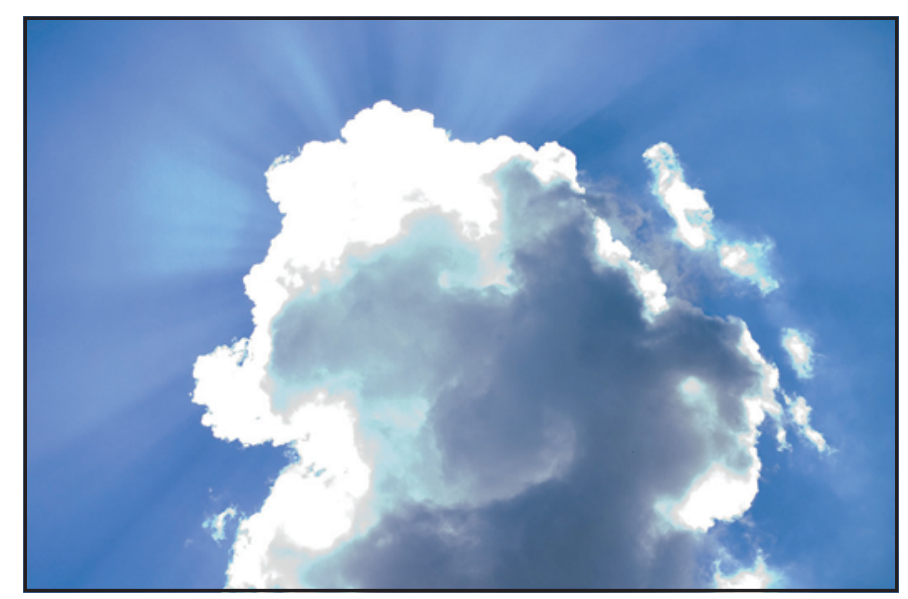




\section{Explosives}

Silver acetylide, silver azide, silver fulminate, silver oxalate, silver styphnate, silver tartrate, and silver tetrazene are silver-based chemicals that have application for explosives. Silver azide is used as a priming compound or detonating agent, a minor but important part of larger explosives (Silver Insights, 2012c). There are no reliable estimates for the amount of silver used or dissipated in this end use.

\section{Mirrors and Reflective Coatings}

About $500 \mathrm{t}$ of silver was used worldwide for the production of plane and spherical mirrors and other reflectors in 2008 (Loterijman, 2008, p. 14). Although mirror scrap can be processed by silver recyclers, data regarding amounts actually processed are unavailable, so there is no information regarding the amount of silver used for this purpose.

\section{Musical Instruments}

Silver has been used for in the manufacture of musical instruments. High-quality flutes and trumpets are made of solid silver, and brass instruments are silver plated. Woodwinds and other instruments frequently have silver or silver-coated key mechanisms (Silver Insights, 2012d).

No information regarding the amount of silver used for musical instruments is available. Musical instruments are not likely to be discarded as scrap, but rather are more likely to be collected by pawn shops and recyclers to be processed for the silver and other metals they may contain. Data regarding amounts actually processed are not available.

\section{Nanosilver}

Silver has long been known as an antibacterial, antifungal, and antiviral agent. Silver biocides make up a growing end use of industrial silver demand. Some of the products and uses for nanosilver include cosmetics, electronics, food packaging, food supplements, household appliances, medical devices, room sprays, textiles, and treatment of public water supplies (U.S. Environmental Protection Agency, 2010, p. 16).

Some human beings are sensitive to a nontoxic but discoloring tissue build-up of silver (argyria). The U.S. Food and Drug Administration (FDA) does not allow the use of any form of silver as a food or animal-feed additive. If used in or on food packaging, the silver must not migrate or be otherwise absorbed into the food. The FDA does not regulate dietary supplements that may contain silver; thus, users ingest these at their own risk (Jeffrey R. Ellis, senior technology consultant, The Silver Institute, written commun., February 11, 2013).

The EPA estimated that silver-treated textiles contain between 0.1 and $0.2 \mathrm{mg}$ of silver per gram of treated textile, and in 2009 , less than $6.8 \mathrm{t}$ of silver was used in the United
States for textile preservatives (U.S. Environmental Protection Agency, 2011b, p. 7, 9). Worldwide, about $500 \mathrm{t}$ of silver was consumed as nanosilver in 2008 (Senjen and Illuminato, 2009, p. 5). Production and consumption data are difficult to locate. Nanosilver is probably a dissipative use, and a scrap market is unlikely to materialize.

\section{Jewelry antd Silverware}

Jewelry and silverware together are a major use for silver. Worldwide silver consumption for jewelry and silverware in 2009 was $6,750 \mathrm{t}$ (28 percent of all silver fabricated), with 73 percent used in jewelry, and 27 percent in silverware. For the United States, consumption for jewelry and silverware in 2009 was $362 \mathrm{t} \mathrm{(7} \mathrm{percent} \mathrm{of} \mathrm{all} \mathrm{silver} \mathrm{fabricated} \mathrm{in} \mathrm{the} \mathrm{United} \mathrm{States),}$ with 92 percent of domestic use for jewelry, and 8 percent for silverware (The Silver Institute, 2011, p. 84, 90, and 92).

\section{Jewelry}

In general, jewelry is purchased as a display of wealth, for aesthetics (design, beauty, and novelty), and as a means to store value. Individuals accumulating high net worth in 2009 allotted 23 percent of their "passion" investment dollars (for art, antiques, boats, club memberships, coins and other collectibles, guns, jets, race horses, sports teams, and other) to all forms of jewelry (crafted metals, gems, and watches) (Capgemini Consulting, 2011, p. 21). Investors with lower net worth have the same reasons for buying jewelry, but they are more likely to buy silver jewelry because the metal is priced well below other precious metals used in jewelry manufacture.

Worldwide, 80 percent of all silver jewelry is fabricated in 10 countries. Thailand, China, Italy, and India together produce 73 percent of that share. The remaining 7 percent is produced in Mexico, the United States, the Republic of Korea, Indonesia, Turkey, and Germany, in order of decreasing magnitude (The Silver Institute, 2011, p. 92-93).

High-grade [scrupulously assayed and uncontaminated] scrap generated in manufacture is often treated onsite. Lowgrade sweeps and polishing dust are collected to be processed at smelters or refineries to recover the precious-metals content (Hoffmann, 2012, p. 2). The demand for old jewelry scrap appears to be greater than the supply of willing sellers at current prices, as the multitude of offers by and locations for buyers seeking old gold and silver jewelry indicates. This imbalance of supply and demand for old jewelry scrap suggests that there is really no such thing as old jewelry scrap, but rather there is a desire (among buyers) to convert the precious metal content of jewelry, which sellers presumably hold for its monetary property (store of value), into physical supply of metal for other uses. The movement of silver in and out of the jewelry category of end uses should be viewed as indicating preferences for competing commodities having monetary properties. The aesthetic character of a piece of jewelry is probably not the most determining factor for a particular jewelry purchase (Clark, 2011). 


\section{Silverware}

Eighty percent of all silverware worldwide is fabricated by India, Russia, China, Italy, Thailand, Turkey, Bangladesh and Nepal, and Germany, in order of decreasing amount, with India, Russia, and China producing 70 percent of that share (The Silver Institute, 2011, p. 94). Silverware can be made from an alloy called sterling, which is 92.5 percent silver, or base metals can be plated with silver. In both cases, the silver can be recovered. Silverware is purchased by commercial gold buyers, who then supply recyclers. The motives for recycling silverware are similar to those for recycling jewelry.

\section{Photography}

For nearly two centuries, photography was a major end use for silver, but the advent of digital photography dramatically decreased silver consumption for this use. From 2001 through 2010, world silver use for photography decreased from 6,630 to $2,260 \mathrm{t}$, a compound rate of 11 percent per year. During the same period, the use of silver for photography in the United States decreased at a compound rate of 12 percent per year (The Silver Institute, 2011, p. 89).

Silver is recycled extensively in the photographic industry for reasons of economics and regulatory compliance. Silver is recovered during processing of bleaches ( 5 to 200 milligrams of silver per liter of solution $(\mathrm{mg} / \mathrm{L}))$, fixes (1,000 to $12,000 \mathrm{mg} / \mathrm{L})$, washes $(1,000$ to $3,000 \mathrm{mg} / \mathrm{L})$, and stabilizers for washless processes (100 to $1,000 \mathrm{mg} / \mathrm{L}$ ) and is practiced generally on the generator's site and using the processor's equipment but with guidance supplied by the recovery consultants. Efficiency for different recovery processes ranges between 90 and 99 percent of silver content (Eastman Kodak Company, 1999, p. 1-3).

Silver recovery from photographic solutions often results in minor amounts of silver being discharged into a water treatment facility. The EPA estimated that raw discharges from 40,000 water treatment facilities in 2003 represented a toxicwaste-potential estimate, attributable to a weight of silver, of 2.54 Mt. This toxic weight factor is a derived number; it represents a level of toxicity equivalent to the toxicity of an equivalent weight of copper. The toxic weight factor for a pound of silver, relative to a pound of copper, is 16 . Dividing the 2.54 million toxic-waste-potential estimate by the toxic weight factor for silver and applying factors to convert pounds into metric tons, $72 \mathrm{t}$ of silver from silver recovery operations in the United States in 2003 was estimated to have entered into water treatment facilities. Water treatment facilities effectively removed 88 percent of that total, discharging $8.6 \mathrm{t}$ of silver into surface waters (U.S. Environmental Protection Agency, 2000, p. 16; 2006, p. 19.21-26). Assuming proportionality with regard to the silver used in photographic operations in the United States in years 2003 and 2009, contained silver entering these water treatment facilities in 2009 was approximately $29 \mathrm{t}$ and (unrecovered) contained silver leaving these same water treatment facilities was $3 \mathrm{t}$.
Silver recycling also includes collection and processing of film. The silver and the polymer (mylar) components of film are both recovered. In 2011, the silver recycling industry processed about 43,000 t of film scrap, which on average contained about 6.2 grams silver per kilogram of scrap, implying that the scrap processed contained about $265 \mathrm{t}$ of silver. X-ray scrap from the medical industry accounted for 95 percent of the film processed, yielding about $252 \mathrm{t}$ of silver to return to the market, most likely in the form of a silver halide, and most likely returned to a manufacturer of x-ray film. Industrial x-ray scrap processing yielded about $8 \mathrm{t}$ of silver, and graphic arts scrap yielded another $5 \mathrm{t}$ of silver in 2011 .

The polymer (mylar) base of the film is sold to recyclers in China and India and returns to the United States after processing. Three processes are used for recovery of the silver; the enzyme process digests a protein into a paste, which is further processed in a furnace; the caustic acid process produces a paste that is further processed in a furnace; and, the DryView process, which is proprietary to Eastman Kodak. Except for a small amount of imports from Canada, imports and exports of silver-containing medical x-ray scrap are virtually zero, the system being more or less a closed loop between manufacturer and recycler (Jim Conroy, owner and operator, Silver Medical Systems, Inc., written commun., July 17, 2012).

\section{Prices}

Except for the 1980 price spike, which was caused by market manipulation (Hilliard, 1999, p. 140), the price of silver has been virtually constant, both in nominal and in constant (2010) dollars, through 2006. The price from 2006 through 2009 has increased slowly. From 2001 through 2010, four trends in U.S. silver fabrication become apparent. Total silver fabricated increased slightly from 5,280 to $5,900 \mathrm{t}$. The amount of silver consumed for photographic applications decreased significantly, from 2,040 to $630 \mathrm{t}$, whereas the amount of silver consumed for industrial applications increased significantly, from 2,450 to $3,570 \mathrm{t}$, roughly offsetting the decrease in photographic use. The amount of silver fabricated into medals and coins increased from 384 to $1,300 \mathrm{t}$, with most of the growth occurring after 2006 (The Silver Institute, 2011, p. 75-94).

Based on available information, it can be concluded that, after 2006, the monetary properties of silver gained preference compared with those of fiat currencies; this preference likely influenced the concurrent increase in the dollar price of silver and the demand for medals and coins. Similarly, the monetary properties of gold gained preference compared with those of fiat currencies, likely leading to the increase of the price of gold. The concurrent increases in the prices of gold and silver were likely the cause behind the stability of the silver-to-gold ratio (about 60). Silver prices, in nominal and in constant dollars (2010 base), from 1977 through 2011, are shown in figure 4, which also shows the ratio of the nominal price of silver to the nominal price of gold. 
Figure 4. Silver price and the silver-to-gold ratio from 1977 through 2011. Values are in dollars, and the silver-to-gold ratio is in troy ounces of silver per troy ounce of gold. Data are from Amey (1999, 2004-2005), Brooks (2006-2011a), George (2006-2011), Hilliard (1999, 2004-2005), and Bureau of Labor Statistics (2012).

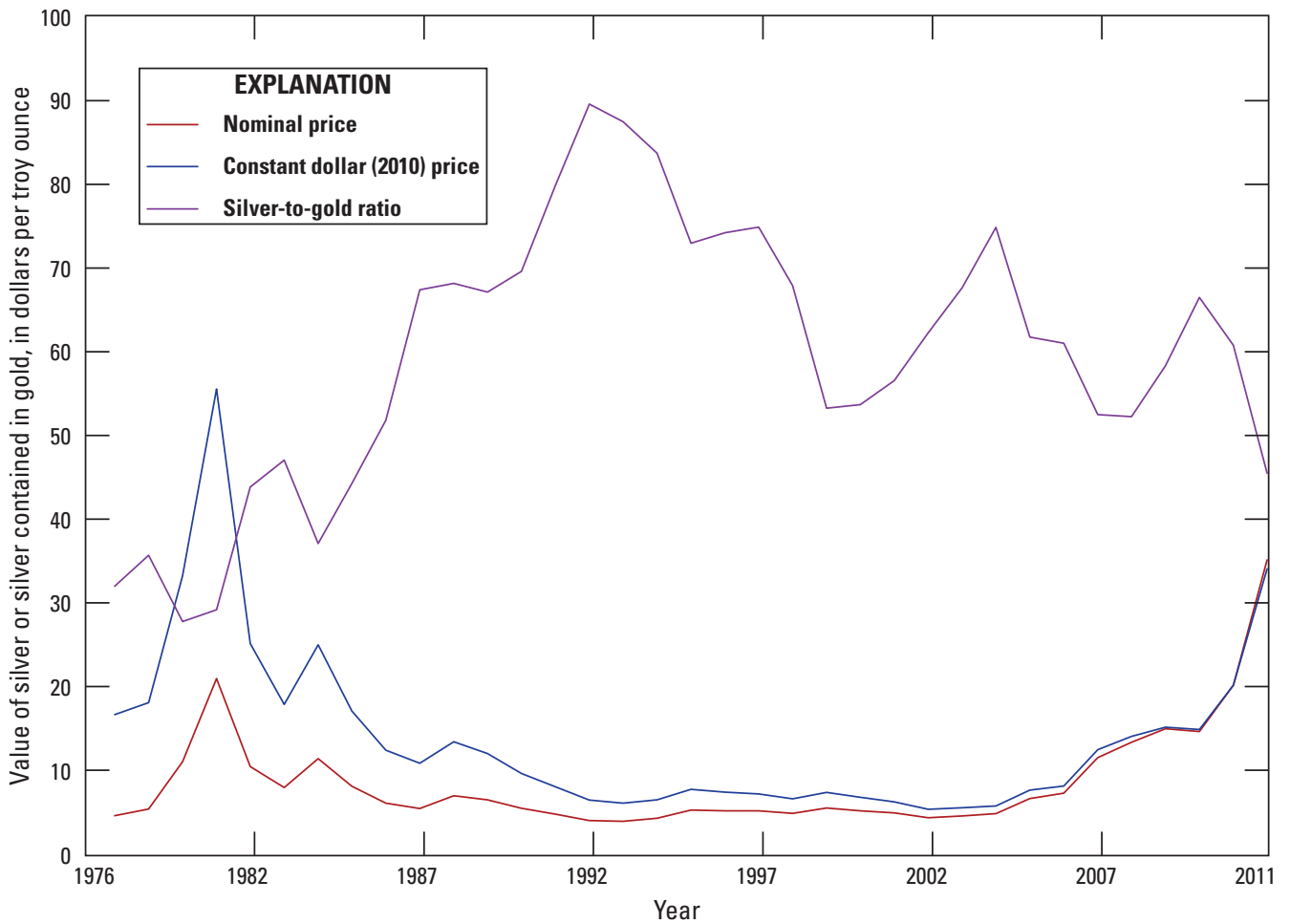

From 2001 through 2010, the average silver scrap rate (silver recovered from scrap as a percentage of total silver production) was 56.4 percent \pm 4 percent for the United States and 23.4 percent \pm 5.3 percent worldwide (The Silver Institute, 2011 , p. 82). For the same period, silver prices (in constant 2010 dollars) continually rose from $\$ 5.38$ per troy ounce in 2001 to $\$ 20.19$ per troy ounce in 2010 . This indicates that, at least for this period, there was little, if any, elasticity in silver scrap use with respect to spot prices for silver.

\section{Outlook}

From 2001 through 2010, world silver production from primary mining grew at a compound annual rate of 2.2 percent per year, at a time when silver spot prices grew by 15.8 percent. The average year-over-year growth of world primary silver production for the period was $1.02 \pm 2.2$ percent, a rather steady growth. Growth in silver production from primary mines should continue at the pace of 2.2 percent per year, regardless of silver spot prices.

Silver is expected to be in demand even if the global economy recovers slowly from the recession of 2008-9. The industrial end use of silver is growing because the use of silver in electric and electronic devices continues to grow with increasing demand for such devices. The use of nanosilver can be expected to increase for health and environmental reasons and because high silver prices will likely lead to innovations in certain applications to use less silver.

There is a large reservoir of aboveground silver that is sequestered in coins and medals and in jewelry and silverware that can be converted into industrial applications as needed at just above the real cost of conversion. This reservoir could potentially counteract foreseeable threats to the silver supply available for industrial applications.

With regard to industrial silver scrap, recycled silver from photographic uses has decreased because less silver is going into this end use; that trend will probably level out as some photographic uses, such as industrial and medical x-ray imaging, are retained. The silver going into solar energy applications will be sequestered for many years, given the long life (30 to 40 years) of such facilities. Legislation governing the disposal of some hazardous waste has created the electronic scrap market. For economic reasons, global recovery activities have gravitated to low-wage areas of the world, such as China. Silver from nanosilver applications may never be recovered in large amounts. If silver prices increase from current levels, recycling and recovery from scrap are likely to increase. However, increased prices would also likely drive technological trends towards less and more widely dispersed use of silver, thereby making future recovery and reclaiming of silver more difficult and costly. 


\section{Selected References}

Amey, E.B., 1999, Gold, in Plunkert, P.A., and Jones, T.S., comps., Metal prices in the United States through 1998: U.S. Geological Survey, p. 49-53.

Amey, E.B., 2003, Gold: U.S. Geological Survey Mineral Commodity Summaries 2003, p. 74-75. (Also available at http://minerals.er.usgs.gov/minerals/pubs/commodity/ gold/300303.pdf.)

Amey, E.B., 2004, Gold: U.S. Geological Survey Mineral Commodity Summaries 2004, p. 72-73. (Also available at http://minerals.er.usgs.gov/minerals/pubs/commodity/gold/ goldmcs04.pdf.)

Amey, E.B., 2005, Gold: U.S. Geological Survey Mineral Commodity Summaries 2005, p. 72-73. (Also available at http://minerals.er.usgs.gov/minerals/pubs/commodity/gold/ gold_mcs05.pdf.)

Appropedia, [undated], Metal reclamation and recycling of electronic waste: Appropedia, accessed August 2, 2012, at http://appropedia.org/Metal_reclamation_and_recycling _ of_electronic_waste.

Arch Metal Refining, 2011, Value of silver oxide batteries: Arch Enterprises, Inc., accessed September 13, 2012, at http://www.precious-metal-refining.info/tag/watch-batteryrecycling/.

Bloch, Richard, 2011, A dollar's worth of "junk silver"-Now north of \$30: Seeking Alpha, accessed August 13, 2012, at http://seekingalpha.com/article/264301-a-dollar-s-worthof-junk-silver-now-worth-over-30.

Brooks, W.E., 2006, Silver: U.S. Geological Survey Mineral Commodity Summaries 2006, p. 152-153. (Also available at http://minerals.usgs.gov/minerals/pubs/commodity/silver/ silvemcs06.pdf.)

Brooks, W.E., 2007, Silver: U.S. Geological Survey Mineral Commodity Summaries 2007, p. 148-149. (Also available at http://minerals.usgs.gov/minerals/pubs/commodity/silver/ silvemcs07.pdf.)

Brooks, W.E., 2008, Silver: U.S. Geological Survey Mineral Commodity Summaries 2008, p. 152-153. (Also available at http://minerals.usgs.gov/minerals/pubs/commodity/silver/ mcs-2008-silve.pdf.)

Brooks, W.E., 2009, Silver: U.S. Geological Survey Mineral Commodity Summaries 2009, p. 148-149. (Also available at http://minerals.usgs.gov/minerals/pubs/commodity/silver/ mcs-2009-silve.pdf.)

Brooks, W.E., 2010, Silver: U.S. Geological Survey Mineral Commodity Summaries 2010, p. 146-147. (Also available at http://minerals.usgs.gov/minerals/pubs/commodity/silver/ mcs-2010-silve.pdf.)
Brooks, W.E., 2011a, Silver: U.S. Geological Survey Mineral Commodity Summaries 2011, p. 146-147. (Also available at http://minerals.usgs.gov/minerals/pubs/commodity/silver/ mcs-2011-silve.pdf.)

Brooks, W.E., 2011b, Silver, in Metals and minerals: U.S. Geological Survey Minerals Yearbook 2009, v. I, p. 68.168.14. (Also available at http://minerals.usgs.gov/minerals/ pubs/commodity/silver/myb1-2009-silve.pdf.)

Brooks, W.E., 2012, Silver, in Metals and minerals: U.S. Geological Survey Minerals Yearbook 2010, v. I, p. 68.1-68.15. (Also available at http://minerals.usgs.gov/minerals/pubs/ commodity/silver/myb1-2010-silve.pdf.)

Buchert, Matthias, Jenseit, Wolfgang, Dittrich, Stefanie, Hacker, Florian, Schüler-Hainsch, Eckhard, Ruhland, Claus, Knöfel, Sven, Goldman, Daniel, Rasenack, Kai, and Treffer, Frank, 2011, Resource efficiency and resource policy aspects of the electro mobility system: Bundesministerium für Umwelt, Naturschutz und Reaktorsicherheit, 103 p., accessed September 19, 2012, at http://www.resourcefever. org/publications/reports/Endbericht_OPTUM\%20 Ressourcen_final_EN.pdf.

Bullock, John, 2005, AML for precious metals-Beyond the final rule: International Precious Metals Institute, Annual Conference, 29, June 12, 2005, Orlando, Florida, Presentation, 14 p., accessed September 19, 2012, at http//www. johnbullock.com/.

Bureau of Labor Statistics, 2012, Producer price index-Commodities: U.S. Department of Labor, Bureau of Labor Statistics, accessed May 18, 2012, at http://www.bls.gov/data/.

Butterman, W.C., and Hilliard, H.E., 2004, Mineral commodity profiles-Silver: U.S. Geological Survey Open-File Report 2004-1251, 40 p. (Also available at http://pubs.usgs. gov/of/2004/1251/.)

Canada Gold Buyers, 2012, How much are scrap silver electrical contacts worth?: Canada-Gold-Buyers, accessed September 10, 2012, at http://www.canada-gold-buyers.com/ how-much-are-scrap-silver-electrical-contacts-worth/.

Capgemini Consulting, 2011, World wealth report, 2011: Capgemini and Merrill Lynch Global Wealth Management, 39 p., accessed October 30, 2012, at http://www.ml.com/ media/114235.pdf.

Carlson, Debbie, 2012, Focus-Solar energy production to grow, but challenges ahead could hit silver use: Kitco News, accessed June 29, 2012, at http://www.kitco.com/reports/ KitcoNews20120321DeC_solar.html.

Chatterjee, S., and Kumar, Krishna, 2009, Effective electronic waste management and recycling process involving formal and non-formal sectors: International Journal of Physical Sciences, v. 4, no. 13, p. 893-905. (Also available at $h t t p: / /$ www.academicjournals.org/ijps/pdf/pdf2009/Dec\%20x/ Chatterjee\%20and\%20Kumar.pdf.) 
Chehade, Youssef, Siddique, Ameer, Alayan, Hisham, Sadasivam, Naveena, Nusri, Saeed, and Ibrahim, Taleb, 2012, Recovery of gold, silver, palladium, and copper from waste printed circuit boards: International Conference on Chemical, Civil and Environmental Engineering, March 24-25, 2012, Dubai, United Arab Emirates, Proceedings, p. 226-234. (Also available at http://psrcentre.org/images/ extraimages/312513.pdf.)

CJ Environmental, Inc., 2012, Silver contacts: CJ Environmental, Inc., accessed September 10, 2012, at http:// cjenvironmental.com/services/silver-refining/silvercontacts/.

Clark, Jeff, 2011, When a gold necklace isn't jewelry: Casey Research, accessed October 31, 2012, at http://www. caseyresearch.com/editorial.php? page $=$ articles/when-goldnecklace-isnt-jewelry\&ppref $=T B P 228 E D 0511 \mathrm{~A}$.

CMW Inc., 2012, Electrical contacts-Silver contacts: CMW Inc., accessed September 10, 2012, at http://www.cmwinc. com/silver-contacts.php.

Crudge, B., Billig, B., and Schneider, R., 2011, Optimize capacity for large ethylene oxide reactors: Hydrocarbon Processing, December 1, accessed July 10, 2012, at http://www.hydrocarbonprocessing.com/Article/2941980/ Optimize-capacity-for-large-ethylene-oxide-reactors.html.

Cui, Jirang, and Zhang, Lifeng, 2008, Metallurgical recovery of metals from electronic waste-A review: Journal of Hazardous Materials, v. 158, nos. 2-3, p. 228-256. (Also

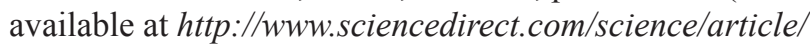
pii/S0304389408002161.)

Department of the Treasury, 2005, Financial crimes enforcement network; anti-money laundering programs for dealers in precious metals, stones, or jewels: Federal Register, v. 70, no. 110, June 9, p. 33702-33718. (Also available at http:// www.gpo.gov/fdsys/granule/FR-2005-06-09/05-11431/ content-detail.html.)

Donahue, D.J., 1957, Methods and means for transferring printed indicia: U.S. Patent Office patent 2796374, [n.p.]. (Also available at http://www.freepatentsonline. com/2796374.pdf.)

Eastman Kodak Company, 1999, Recovering silver from photographic processing solutions: Eastman Kodak Company, 12 p., accessed July 16, 2012 at http://www.kodak.com/ek/ uploadedFiles/J215ENG.pdf.

Eisler, Ronald, 1996, Silver hazards to fish, wildlife, and invertebrates-A synoptic view: National Biological Service Biological Report 32, September, 44 p. (Also available at $h t t p: / /$ www.pwrc.usgs.gov/infobase/eisler/CHR_32_Silver.pdf.)

Environmental Chemistry, 2012, Periodic table of elements, element silver, Ag: Environmental Chemistry, accessed May 14, 2012, at http://environmentalchemistry.com/yogi/ periodic/Ag.html.
Etris, Samuel, 2007, Our electrical world needs tons of silver: Silver News, fourth quarter, p. 1, accessed February 12, 2013, at http://www.minesmanagement.com/images/pdfs/ Silver_News/2007-Q4.pdf.

Firman, Carl, Loterijman, Marina, Highcloud, Sierra, and Mead, Gary, 2011, The silver book: ABN AMRO Bank N.V., and VM Group, 2011, 43 p., accessed October 16, 2012, at http://www.virtualmetals.co.uk/pdf/ABNSB0711. $p d f$.

Fisher, Karen, Wallén, Erika, Laenen, P.P., and Collins, Michael, 2006, Battery waste management life cycle assessment: Environmental Resource Management, Ltd., United Kingdom, 132 p. plus annexes, accessed September 12, 2012, at http://www.epbaeurope.net/090607_2006_Oct.pdf.

George, M.W., 2006, Gold: U.S. Geological Survey Mineral Commodity Summaries 2006, p. 66-67. (Also available at http://minerals.er.usgs.gov/minerals/pubs/commodity/gold/ gold_mcs06.pdf.)

George, M.W., 2007, Gold: U.S. Geological Survey Mineral Commodity Summaries 2007, p. 70-71. (Also available at http://minerals.er.usgs.gov/minerals/pubs/commodity/gold/ gold_mcs07.pdf.)

George, M.W., 2008, Gold: U.S. Geological Survey Mineral Commodity Summaries 2008, p. 72-73. (Also available at http://minerals.er.usgs.gov/minerals/pubs/commodity/gold/ mcs-2008-gold.pdf.)

George, M.W., 2009, Gold: U.S. Geological Survey Mineral Commodity Summaries 2009, p. 68-69. (Also available at http://minerals.er.usgs.gov/minerals/pubs/commodity/gold/ mcs-2009-gold.pdf.)

George, M.W., 2010, Gold: U.S. Geological Survey Mineral Commodity Summaries 2010, p. 66-67. (Also available at http://minerals.er.usgs.gov/minerals/pubs/commodity/gold/ mcs-2010-gold.pdf.)

George, M.W., 2011, Gold: U.S. Geological Survey Mineral Commodity Summaries 2011, p. 66-67. (Also available at http://minerals.er.usgs.gov/minerals/pubs/commodity/gold/ mcs-2011-gold.pdf.)

Goosey, Martin, and Kellner, Rod, 2002, A scoping study, endof-life printed circuit boards: Intellect and Shipley Europe Limited, 44 p., accessed September 17, 2012, at http://cfsd. org.uk/seeba/TD/reports/PCB_Study.pdf.

Griffith, D.A., and Yorty, D.P., 2009, Weather modification feasibility study for upper Boise River basin, Idaho: Idaho Water Resource Board Report WM 09-12, [variously paged]. (Also available at http://www.idwridaho. gov/WaterBoard/WaterPlanning/CAMP/TV_CAMP/ PDF/2010/09-29-2010_Weather_Mod.pdf.) 
Hagelüken, Christian, 2007, Metals recovery from e-scrap in a global environment: Open-Ended Working Group Basel Convention, meeting, 6th, Geneva, Switzerland, September 7, 2007, presentation, 51 p., accessed July 27, 2012, at http:// archive.basel.int/industry/sideevent030907/umicore.pdf.

Hagelüken, Christian, and Verheist, Michel, 2004, Recycling of precious metal catalysts: Umicore Precious Metals Refining, 3 p., accessed September 4, 2012, at http://www. preciousmetals.umicore.com/PMR/Media/industrialCats/ show_recyclingOfPreciousMetalCatalysts.pdf.

Handbook of Chemistry and Physics, 1988, Electrical resistivity and temperature coefficients of elements, in Weast, R.C., ed., Handbook of chemistry and physics (1st student ed.): Boca Raton, Florida, CRC Press, p. F88.

Hecla Mining Company, 2013, Greens Creek, processing: Hecla Mining, accessed April 8, 2013 at http://www.heclamining.com/operations/operations_greenscreek_processing. php.

Hilliard, H.E., 1999, Silver, in Plunkert, P.A., and Jones, T.S., comps., Metal prices in the United States through 1998: U.S. Geological Survey, p. 139-142.

Hilliard, H.E., 2004, Silver: U.S. Geological Survey Mineral Commodity Summaries 2004, p. 150-151. (Also available at http://minerals.er.usgs.gov/minerals/pubs/commodity/ silver/silvemcs04.pdf.)

Hilliard, H.E., 2005, Silver: U.S. Geological Survey Mineral Commodity Summaries 2005, p. 150-151. (Also available at http://minerals.er.usgs.gov/minerals/pubs/commodity/ silver/silvemcs05.pdf.)

Hoffmann, J.F., 2012, Silver processing: Encyclopædia Britannica, Inc., accessed May 9, 2012, at http://www.britannica. com/EBchecked/topic/544891/silver-processing/81559/ Additional-Reading.

Huang, Janet, Resendez, Daniel, and Tran, Gina, 1999, Ethylene oxide reactor system: Davis Corporation, October 8, accessed July 10, 2012, at http://www.owlnet.rice. edu/ ceng403/gr1599/finalreport3.html.

Huisman, Jaco, Magalini, Federico, Keuhr, Ruediger, Maurer, Claudia, Ogilvie, Steve, Poll, Jim, Delgado, Clara, Artim, Eniko, Szlezak, Joseph, and Stevels, Ab, 2007, Waste electrical and electronic equipment (WEEE): Bonn, Germany, United Nations University, August 5, 347 p. plus 15 annexes. (Also available at http://ec.europa.eu/environment) waste/weee/pdf/final_rep_unu.pdf.)

Kahhat, Ramzy, Poduri, Soumya, and Williams, Eric, 2011, Bill of attributes (BOA) in life cycle modeling of laptop computers - Results and trends from disassembly studies: Sustainability Consortium White Paper 103, 19 p, accessed September 17, 2012, at http://www.researchfindr.com/ bill-attributes-boa-life-cycle-modeling-laptop-computersresults-and-trends-disassembly-studies.
Kramer, D.A., 2013, Silver, in Metals and minerals: U.S. Geological Survey Minerals Yearbook 2011, p. 68.1-68.14, accessed August 6, 2013, at http://minerals.usgs.gov/ minerals/pubs/commodity/silver/myb1-2011-silve.pdf.)

Krauter, Jürgen, 2012, Refining of precious metal powder spent catalysts: Evonik Industries AG, 19 p., accessed September 4, 2012, at http://catalysts.evonik.com/sites/dc/ Downloadcenter/Evonik/Product/Catalysts/Brochures/381_ document.pdf.

Krothapalli, Anjaneyulu, and Greska, Brenton, 2011, Concentrated solar thermal power: Florida State University, 32 p., accessed October 17, 2012, at http://esc.fsu.edu/documents/ CSP/Krothapalli\%20Article.pdf.

Lanzano, T., Bertram, M., De Palo, M., Wagner, C., Zyla, K., and Graedel, T.E., 2005, The contemporary European silver cycle: Resources Conservation and Recycling, v. 46, p. 27-43. (Also available at http://www.bvsde.paho.org/ bvsacd/cd43/zyla.pdf.)

Loterijman, Marina, 2008, Silver market outlook: Global Capital Magazine, February, p. 12-16, accessed October 16, 2012, at http://www.virtualmetals.co.uk/pdf/Global\%20 Capital\%20Magazine\%20-\%20Silver\%20market\%20 outlook.pdf.

Maltby, Van, McLaughlin, Doug, and Unwin, Jay, 2005, Fate of copper and silver from RFID labels during recycling of OCC and potential environmental and product implications: Kalamazoo, Michigan, National Council for Air and Stream Improvement, 20 p. plus appendixes. (Also available at http://www.fibrebox.org/upload/2011/RFID/FBA\%20 Report-RFID\%20Ver\%20071405\%20final.pdf.)

MexZotic, 2012, Silver facts: MexZotic, accessed September 13, 2012, at http://www.mexzotic.com/Silver-Facts.aspx.

Microbattery, 2012, Technical specifications-Energizer silver oxide batteries: Microbattery, accessed September 14, 2012, at http://www.microbattery.com/tech-energizer-silver-oxide.htm.

Minco Silver Corporation, 2012, Minco Silver Corporation: Minco Silver Corporation, 28 p., accessed July 26, 2012, at http://www.mincosilver.ca/i/pdf/PPT-MSU.pdf.

Nadal, David, Serman, Dana, and Badlani, Dilip, 2011, Silver demand creates small-cap opportunities: Royce Funds, 8 p., accessed September 11, 2012, at http://www.roycefunds. com/Advisors/pdf/silver-brochure.pdf.

Nexant Chem Systems, 2006, PERP program-Formaldehyde and derivatives: Nexant Chem Systems, July, 9 p., accessed September 4, 2012, at http://www.chemsystems.com/reports/ search/docs/abstracts/0405S10_abs.pdf.

North Carolina Department of Environment, Health, and Natural Resources, 1992, Silver recovery systems and waste reduction in photoprocessing: Printers' National Environmental Assistance Center fact sheet, accessed May 11, 2012, at http://www.pneac.org/sheets/all/silver.cfm. 
Porter, K.E., Hilliard, H.E., and Brooks, W.E., 2011, Silver end-use statistics, in Kelly, T.D., and Matos, G.R., comps., 2011, Historical statistics for mineral and material commodities in the United States, silver, end-use statistics: U.S. Geological Survey Data Series 140 [2011 revision], accessed May 2, 2012, at http://minerals.usgs.gov/ $d s / 2005 / 140 /$.

Recycling Today, 2003, Is lead's loss silver's gain: Highbeam Research, accessed June 21, 2012, at http://www.highbeam. com/doc/1G1-100608244.html.

RIS International, 2007, Canadian consumer battery baseline study: Environment Canada, February, 90 p., accessed September 12, 2012, at http://www.docstoc.com/ docs/79783916/Canadian-Consumer-Battery-BaselineStudy-Final-Report.

Ruff, H.J., 2008, How to prosper during the coming bad year in the 21st century: Ruff Times, March 7, 2008. Accessed Kitco Commentator's Corner June 15, 2012 at http://www. kitco.com/ind/Ruff/ruff_mar072008.html.

Senjen, Rye, and Illuminato, Ian, 2009, Nano and biocidal silver: Friends of the Earth, June, 44 p., accessed May 30, 2012, at http://libcloud.s3.amazonaws.com/93/b3/3/636/ Nano_and_biocidal_silver.pdf.

Sheppard, L.M., and Cavette, Chris, 2012, Cathode ray tube: How Products Are Made, v. 2, accessed September 20, 2012, at http://www.madehow.com/Volume-2/Cathode-Ray-Tube.html.

Sherwood, Larry, 2011, U.S. solar market trends 2010: Interstate Renewable Energy Council, June, 20 p., accessed October, 18, 2012, at http://irecusa.org/wp-content/ uploads/2011/06/IREC-Solar-Market-Trends-Report-June2011-web.pdf.

Silver Insights, 2012a, Silver uses_-Bearings: Silver Insights, accessed September 10, 2012, at http://www.silverinsights. $\mathrm{com} /$.

Silver Insights, 2012b, Silver uses-Electronics: Silver Insights, accessed September 6, 2012, at http://www. silverinsights.com/.

Silver Insights, 2012c, Silver uses-Explosives: Silver Insights, accessed September 23, 2012, at http://www. silverinsights.com/.

Silver Insights, 2012d, Silver uses-Musical instruments: Silver Insights, accessed October 30, 2012, at http://www. silverinsights.com/.

Silver Insights, 2012e, Silver uses-Superconductivity: Silver Insights, accessed September 22, 2012, at http://www. silverinsights.com/.

Silver Institute, The, 2011, World silver survey 2011: Washington, D.C., The Silver Institute, 100 p.

Silver Institute, The, 2012a, Silver catalysts: The Silver Institute, accessed May 1, 2012, at http://www.silverinstitute. org/site/silver-in-industry/catalysts/.
Silver Institute, The, 2012b, Silver in batteries: The Silver Institute, accessed May 1, 2012, at http://www. silverinstitute.org/site/silver-in-industry/batteries/.

South Australia Department of Manufacturing, Innovation, Trade, Resources, and Energy, 2012, Silver: South Australia Department of Manufacturing, Innovation, Trade, Resources, and Energy, accessed August 2, 2013, at http:// www.minerals.dmitre.sa.gov.au/sarig2/metadata/mines and_minerals_deposits/by_commodity/silver.

St. Angelo, Steve, 2012, First time ever-Silver sales surpass domestic production: Financial Sense, January 4, accessed August 16, 2012 at http://www.financialsense.com/ contributors/steve-angelo/2012/01/04/silver-sales-surpassdomestic-production.

Sullivan, D.E., 2006, Recycled cell phones-A treasure trove of valuable metals: U.S. Geological Survey Fact Sheet 2006-3097, 4 p. (Also available at http://pubs.usgs.gov/ $f_{s} / 2006 / 3097 /$.)

U.S. Environmental Protection Agency, 2000, Cost-effectiveness analysis of proposed effluent limitations guidelines and standards for the metal products and machinery industry: U.S. Environmental Protection Agency EPA821-B-00-007, December, 25 p., accessed May 18, 2012, at http://water.epa.gov/scitech/wastetech/guide/mpm/ upload/2001_01_10_guide_mpm_proposal_mpm_ce.pdf.

U.S. Environmental Protection Agency, 2006, Technical support document for the 2006 effluent guidelines program plan: U.S. Environmental Protection Agency EPA821R-06-108, December, [variously paged], accessed May 18, 2012, at http://water.epa.gov/lawsregs/lawsguidancel cwa/304m/upload/2007_01_10_guide_304m_2006_2006TSD-whole.pdf.

U.S. Environmental Protection Agency, 2010, State of the science literature review-Everything nanosilver and more: U.S. Environmental Protection Agency EPA/600/R-10/084, August, 363 p., accessed May 14, 2012, at http://www.epa. gov/nanoscience/files/NanoPaper1.pdf.

U.S. Environmental Protection Agency, 2011a, Electronics waste management in the United States through 2009: U.S. Environmental Protection Agency EPA 530R-11-002, May, 49 p., accessed June 7, 2012, at http:// www.epa.gov/osw/conserve/materials/ecycling/docs/ fullbaselinereport2011.pdf.

U.S. Environmental Protection Agency, 2011b, EPA response to comments received on proposed decision document for the registration of HeiQ AGS-20 as a materials preservative in textiles: U.S. Environmental Protection Agency EPA-HQ-OPP-2009-1012, December 1, 55 p., accessed October 24, 2012, at http://op.bna.com/env.nsf/id/mdas8p6me4/\$File/Nanosilverresponse.pdf.

Zurbuchen, David, 2006, The real silver deficit: Safe Haven, accessed May 7, 2012, at http://www.safehaven.com/ article/5204/the-real-silver-deficit. 

Prepared by the Pembroke and Raleigh Publishing Service Centers

For more information about this publication, contact:

Director

U.S. Geological Survey

National Minerals Information Center

12201 Sunrise Valley Drive

Reston, VA 20192

nmicrecordsmgt@usgs.gov

or visit our Web site at

http://minerals.usgs.gov/minerals/ 
